\title{
Spatiotemporal variation and trends in equivalent black carbon in the Helsinki metropolitan area in Finland
}

\author{
Krista Luoma ${ }^{1}$, Jarkko V. Niemi ${ }^{2}$, Minna Aurela ${ }^{3}$, Pak Lun Fung ${ }^{1}$, Aku Helin ${ }^{3}$, Tareq Hussein ${ }^{1,5}$, Leena Kangas ${ }^{2}$, \\ Anu Kousa ${ }^{2}$, Topi Rönkkö ${ }^{4}$, Hilkka Timonen ${ }^{3}$, Aki Virkkula ${ }^{3}$, and Tuukka Petäjä ${ }^{1}$ \\ ${ }^{1}$ Institute for Atmospheric and Earth System Research/Physics, Faculty of Science, University of Helsinki, \\ P.O. Box 68, 00014 Helsinki, Finland \\ ${ }^{2}$ Helsinki Region Environmental Services Authority, P.O. Box 100, 00066 Helsinki, Finland \\ ${ }^{3}$ Atmospheric Composition Research, Finnish Meteorological Institute, P.O. Box 503, 00101 Helsinki, Finland \\ ${ }^{4}$ Aerosol Physics Laboratory, Faculty of Engineering and Natural Sciences, Tampere University, \\ P.O. Box 692, 33014 Tampere, Finland \\ ${ }^{5}$ Department of Physics, The University of Jordan, 11942 Amman, Jordan
}

Correspondence: Krista Luoma (krista.q.luoma@helsinki.fi)

Received: 2 March 2020 - Discussion started: 29 April 2020

Revised: 17 November 2020 - Accepted: 1 December 2020 - Published: 28 January 2021

\begin{abstract}
In this study, we present results from 12 years of black carbon (BC) measurements at 14 sites around the Helsinki metropolitan area (HMA) and at one background site outside the HMA. The main local sources of BC in the HMA are traffic and residential wood combustion in fireplaces and sauna stoves. All BC measurements were conducted optically, and therefore we refer to the measured $\mathrm{BC}$ as equivalent $\mathrm{BC}(\mathrm{eBC})$. Measurement stations were located in different environments that represented traffic environment, detached housing area, urban background, and regional background. The measurements of eBC were conducted from 2007 through 2018; however, the times and the lengths of the time series varied at each site. The largest annual mean eBC concentrations were measured at the traffic sites (from 0.67 to $2.64 \mu \mathrm{g} \mathrm{m}^{-3}$ ) and the lowest at the regional background sites (from 0.16 to $0.48 \mu \mathrm{g} \mathrm{m}^{-3}$ ). The annual mean eBC concentrations at the detached housing and urban background sites varied from 0.64 to $0.80 \mu \mathrm{g} \mathrm{m}^{-3}$ and from 0.42 to $0.68 \mathrm{~g} \mathrm{~m} \mathrm{~m}^{-3}$, respectively. The clearest seasonal variation was observed at the detached housing sites where residential wood combustion increased the eBC concentrations during the cold season. Diurnal variation in eBC concentration in different urban environments depended clearly on the local sources that were traffic and residential wood combustion. The dependency was not as clear for the typically measured air quality parameters, which were here $\mathrm{NO}_{x}$
\end{abstract}

concentration and mass concentration of particles smaller that $2.5 \mu \mathrm{m}$ in diameter $\left(\mathrm{PM}_{2.5}\right)$. At four sites which had at least a 4-year-long time series available, the eBC concentrations had statistically significant decreasing trends that varied from $-10.4 \% \mathrm{yr}^{-1}$ to $-5.9 \% \mathrm{yr}^{-1}$. Compared to trends determined at urban and regional background sites, the absolute trends decreased fastest at traffic sites, especially during the morning rush hour. Relative long-term trends in eBC and $\mathrm{NO}_{x}$ were similar, and their concentrations decreased more rapidly than that of $\mathrm{PM}_{2.5}$. The results indicated that especially emissions from traffic have decreased in the HMA during the last decade. This shows that air pollution control, new emission standards, and a newer fleet of vehicles had an effect on air quality.

\section{Introduction}

Air pollution is one of the biggest environmental health risks in the world. Air pollution consists of both gaseous components and particulate matter (PM). Lelieveld et al. (2015) estimated that particles smaller than $2.5 \mu \mathrm{m}$ in diameter $\left(\mathrm{PM}_{2.5}\right)$ and ozone $\left(\mathrm{O}_{3}\right)$ together caused about 3.3 million premature deaths globally in 2010. A majority of these premature deaths were due to $\mathrm{PM}_{2.5}$ (approximately 1.9 million). More than $65 \%$ of the premature deaths caused by $\mathrm{PM}_{2.5}$ were re- 
lated to cardiovascular diseases, the second largest cause for the $\mathrm{PM}_{2.5}$-related premature deaths were lung and respiratory diseases, and a small fraction was due to lung cancer (Lelieveld et al., 2015). The causes for the adverse health effects of PM are the PM-induced inflammation and toxic materials which are transported in the respiratory system by the particles.

The WHO reported that PM emitted from combustion sources, especially from traffic, is more harmful for health than PM from other sources (Krzyżanowski et al., 2005). Typical combustion sources, which are also discussed in this study, are traffic and domestic wood burning. Traffic emits a complex mixture of gaseous and fine particulate compounds (Rönkkö and Timonen, 2019). Domestic wood burning also emits fine particles that include toxic compounds, such as benzo(a)pyrene (Hellén et al., 2017). Black carbon (BC), which is defined as black carbonaceous particulate matter, is a good indicator of pollution from combustion because it is a side product of incomplete combustion. Therefore, measuring $\mathrm{BC}$ alongside the other air quality parameters can give additional information about the health effects of PM (Janssen et al., 2011). BC is not just an indicator of bad air quality, but the $\mathrm{BC}$ particles themselves also have adverse health effects. BC particles, which are around the size range of $\sim 100 \mathrm{~nm}$, can penetrate deep in the respiratory system and all the way to the alveolar region where the particles can be transported in the blood circulation system and further on into the organs.

Due to its black appearance, BC absorbs solar radiation and decreases the albedo of reflecting surfaces (i.e., snow and ice sheets). BC has been estimated to be one of the greatest warming agents in climate change (Stocker et al., 2013). Since BC is emitted in the air as particles, its lifetime in the atmosphere is relatively short (a few weeks) compared to greenhouse gases (tens of years). Therefore, in addition to improving air quality, cutting down the $\mathrm{BC}$ emissions would have rather fast effects in the radiative forcing slowing down the rate of global warming. In order to reduce BC emissions, there has been, for example, a suggestion of implementing a $\mathrm{BC}$ footprint similar to the $\mathrm{CO}_{2}$ footprint (Timonen et al., 2019).

Several recent studies have reported decreasing long-term trends in $\mathrm{BC}$ concentration in different types of environments including urban areas (e.g., Sun et al., 2020; Kutzner et al., 2018; Singh et al., 2018; Font and Fuller, 2016). In Finland, the concentration of $\mathrm{BC}$ and its trends have been studied especially in background sites (Hienola et al., 2013; Hyvärinen et al., 2011) but not that much in urban areas. The previous studies about $\mathrm{BC}$ concentrations in the Helsinki metropolitan area (HMA) were mainly from shorter campaigns (Aurela et al., 2015; Dos Santos-Juusela et al., 2013; Helin et al., 2018; Järvi et al., 2008; Pakkanen et al., 2000; Pirjola et al., 2017).

The objective of this study is to investigate the spatiotemporal variability of $\mathrm{BC}$ in different types of environments in the HMA. Our objective is also to clarify how the proximity of combustion sources, which in HMA are mainly traffic and residential wood combustion (Helin et al., 2018; Savolahti et al., 2016), affected the BC concentrations. In this study, we utilize $\mathrm{BC}$ data measured at various different locations in the HMA and at one site outside the HMA. The measurements were conducted during 2007-2018. To study how the variability of BC differed from the variability of the monitored and regulated air quality parameters, we also included parallel measurements of $\mathrm{PM}_{2.5}$ and $\mathrm{NO}_{x}$ in this study.

\section{Measurements and methods}

\subsection{The field sites}

The HMA consists of four different cities (Helsinki, Espoo, Vantaa, and Kauniainen), and it is the most densely populated area in Finland. In 2020, the total population in the HMA was about 1.4 million. Helsinki is the capital of Finland, and it is located on the southern coast of the country $\left(60^{\circ} 10^{\prime} \mathrm{N}, 24^{\circ} 56^{\prime} \mathrm{E}\right)$. The HMA is situated on the seaside of the Gulf of Finland, and therefore the climate in the area is a transition zone between oceanic and continental climate and is typically defined as a humic continental climate. On average, the coldest month during the measurement period (2009-2018) was February $\left(-5^{\circ} \mathrm{C}\right)$, and the warmest month was July $\left(19^{\circ} \mathrm{C}\right)$. The mean wind speed over the whole measurement period was about $4 \mathrm{~m} \mathrm{~s}^{-1}$. For more detailed information about the meteorological parameters, see Fig. S1.

The measurements of $\mathrm{BC}$ concentration were conducted at 15 sites. We classified the stations into four categories: traffic site (TR), detached housing area (DH), urban background (UB), and regional background (RB). The locations of the measurement sites are presented in Fig. 1; the exact coordinates and aerial photos of the stations are provided in Sect. S2 in the Supplement. A total of 14 of the measurements sites were located in the HMA, and one of the RB sites was located circa $200 \mathrm{~km}$ north of the HMA in Hyytiälä. At some of the stations, the measurements have been repeated or conducted on a long-term basis, and at some of the stations, the measurements lasted only for 1 year. The measurement periods for each site are given in Table 1.

Six traffic stations, TR1-TR6, were located close to a busy street or road (Sect. S2.1). At these sites, traffic was the dominant source of pollution. Detailed information, such as traffic counts (TCs), fraction of heavy-duty vehicles (HD; i.e., trucks and buses), and the distance of the station to the closest traffic lines are presented in Table 2.

Detached housing stations, DH1-DH5, were located in residential areas that consisted of separate one-family houses, small streets, and some forests and parks (Sect. S2.2). The traffic rates at these areas were low; for example, the traffic rates on the streets next to DH1 and DH5 were about 2600 vehicles per day, which was significantly less than at the TR sites (Table 2). According to a survey study, up to 


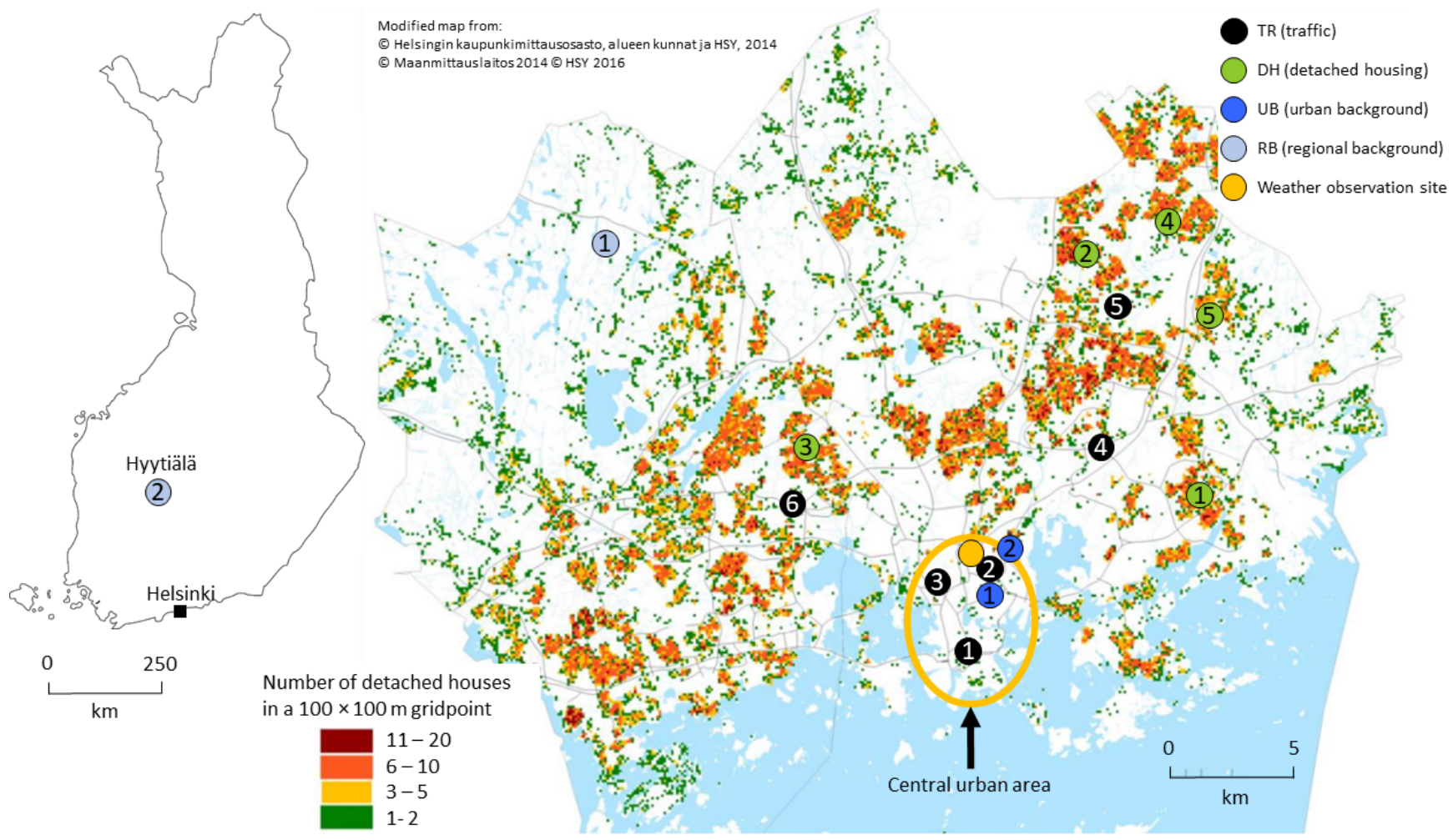

Figure 1. Location of the stations and density of the detached houses. Differently colored markers indicate different station categories. The central urban area is marked on the map with an orange circle.

Table 1. Annual mean values of eBC concentration for each station (in units of $\mu \mathrm{g} \mathrm{m}^{-3}$ ). The annual means at UB2 in $2016-2017$ are bracketed since there was less than $50 \%$ of valid data.

\begin{tabular}{lcccccccccccc}
\hline Station & 2007 & 2008 & 2009 & 2010 & 2011 & 2012 & 2013 & 2014 & 2015 & 2016 & 2017 & 2018 \\
\hline TR1 & & & & & 1.27 & & 0.90 & 0.81 & 0.72 & 0.80 & 0.68 & 0.73 \\
TR2 & & & & & & & & & 1.35 & 1.24 & 1.08 & 0.99 \\
TR3 & & & & 2.64 & & & & & 1.55 & & & \\
TR4 & & & & & & 1.58 & & & & & & \\
TR5 & & & & & & & & 0.91 & & 0.76 & & 0.83 \\
TR6 & & & 0.80 & & & & & & 0.88 & & 0.67 & \\
DH1 & & & & & & & & 0.80 & & & & \\
DH2 & & & & & & & & & & 0.65 & & \\
DH3 & & & & & & & & & & & 0.64 & \\
DH4 & & & & & & & & & & & & 0.74 \\
DH5 & & & & & & 0.68 & 0.59 & 0.53 & 0.52 & 0.50 & 0.42 & 0.49 \\
UB1 & & & & & & & & & 0.54 & $(0.56)$ & $(0.44)$ & 0.50 \\
UB2 & & & & & & & & & & 0.26 & & 0.29 \\
RB1 & & & & & & & & & & & \\
RB2 & 0.31 & 0.38 & 0.33 & 0.39 & 0.33 & 0.48 & 0.19 & 0.24 & 0.19 & 0.20 & 0.16 & 0.19 \\
\hline
\end{tabular}

$90 \%$ of the one-family households burned wood to warm up houses and/or saunas, but less than $2 \%$ of the households used wood combustion as the main heating source (HSY, 2016, in Finnish only; Hellén et al., 2017).

Background sites were categorized as urban and regional background sites. Urban background stations, UB1 and UB2, were located close to the central area but not in the vicinity of busy roads (Sect. S2.3). UB2 is also known as SMEAR III (Station for Measuring Ecosystem-Atmosphere Relations; Järvi et al., 2009). Regional background stations RB1 and RB2 were located in rural areas about 20 and $200 \mathrm{~km}$ away from Helsinki, respectively (Sect. S2.3). RB sites represented 
Table 2. Traffic counts for working days at the nearest streets to the TR sites. Traffic counts and the fraction of the heavy-duty vehicles are from the yearly Helsinki traffic reports. The streets and roads mentioned here are marked in Fig. S3.

\begin{tabular}{llrrrr}
\hline Station & Street name & $\begin{array}{r}\text { Traffic count } \\
\text { (vehicles/weekday) }\end{array}$ & $\begin{array}{r}\text { Heavy-duty } \\
\text { vehicles }(\%)\end{array}$ & $\begin{array}{r}\text { Distance to street } \\
\text { edge (m) }\end{array}$ & $\begin{array}{r}\text { Reference } \\
\text { year }\end{array}$ \\
\hline \multirow{2}{*}{ TR1 } & Mannerheimintie & 15800 & 11 & 3 & 2017 \\
& Kaivokatu & 20100 & 8 & 40 & 2017 \\
\hline TR2 & Mäkelänkatu & 28100 & 11 & 0.5 & 2017 \\
\hline TR3 & Mannerheimintie & 44400 & 14 & 0.5 & 2010 \\
& Reijolankatu & 19400 & - & 25 & 2010 \\
\hline TR4 & Kehä I & 69200 & 8 & 5 & 2012 \\
& Tattariharjuntie & 13700 & 13 & 120 & 2012 \\
\hline TR5 & Tikkurilantie & 9500 & - & 7 & 2016 \\
\hline TR6 & Turuntie & 29300 & 4 & 20 & 2017 \\
& Lintuvaarantie & 15400 & 5 & 30 & 2017 \\
& Kehä I & 68900 & 4 & 250 & 2017 \\
\hline
\end{tabular}

the concentration levels outside the urban area without local pollution sources. RB2 is also part of the SMEAR network and is better known as SMEAR II (Hari and Kulmala, 2005).

The Helsinki Region Environmental Services Authority (HSY), which is the authority monitoring the air quality in the HMA, arranged the measurements at 13 of the sites. The Institute for Atmospheric and Earth System Research (INAR) arranged the measurements at RB2, and the Finnish Meteorological Institute (FMI), together with INAR, conducted the measurements at UB2.

\subsection{Measurements of equivalent black carbon}

All BC measurements were conducted optically, meaning that the $\mathrm{BC}$ concentration was derived from the light absorption of the particles, and hence we refer to the measured BC as equivalent black carbon (eBC; Petzold et al., 2013). At 11 of the stations, the measurements of $\mathrm{eBC}$ were conducted by using only a multi-angle absorption photometer (MAAP; Thermo Fisher Scientific, model 5012), and at three of the stations (DH4, DH5, and RB2), all or at least part of the measurements were conducted by using an aethalometer (Magee Scientific, models AE31 and AE33). The instruments used at the different sites are listed in Table S1.

At all of the stations, the head of the sampling line was located $4 \mathrm{~m}$ above the ground. The concentration of $\mathrm{eBC}$ was measured for particles smaller than $1 \mu \mathrm{m}\left(\mathrm{PM}_{1}\right)$. However, at $\mathrm{DH} 1$, the eBC concentration was measured for $\mathrm{PM}_{2.5}$ for the first half of the year, but since most of the $\mathrm{BC}$ particles are smaller than $1 \mu \mathrm{m}$ in diameter (Vallius et al., 2000), the cutoff size should not have caused a big difference in the results. Sample air was dried with an external dryer or by warming up the sample to $40^{\circ} \mathrm{C}$ at most of the stations, but at TR1, UB2, DH5, and DH4 (only the first half of the year), the sample air was not dried. Even if there was no drier, the sample was air warmed up to room temperature, which decreased the RH when the outdoor temperature was lower than the indoor temperature (i.e., the sample air was dried passively during the cold period; however, in summer, when the temperature difference was smaller, the RH did not necessarily decrease).

The MAAP determines the absorption coefficient of aerosol particles by collecting the particles on a filter medium and by measuring the intensity of light penetrating the filter and the intensity of light that is scattered from the filter at two different angles (Petzold and Schönlinner, 2004). The absorption coefficient is determined from these measurements by using a radiative transfer scheme. The eBC concentration is obtained from the absorption coefficient by using a mass absorption cross-section (MAC) value of $6.60 \mathrm{~m}^{2} \mathrm{~g}^{-1}$ (Petzold and Schönlinner, 2004). The MAAP operates only at one wavelength, which is $637 \mathrm{~nm}$.

The aethalometer measures the $\mathrm{eBC}$ concentration at seven wavelengths $(370,470,520,590,660,880$, and $950 \mathrm{~nm})$. Here we chose to use the $880 \mathrm{~nm}$ channel since it is the recommended and most commonly used wavelength to report the eBC measured by an aethalometer. Similar to the MAAP, the aethalometer collects the sample aerosol particles on the filter material, but unlike the MAAP, the aethalometer only measures the attenuation of light through the filter. Therefore, the aethalometer is prone to error caused by the increasing filter loading. In the newer model, AE33, this is automatically taken into account in real time as the instrument applies the so-called "dual-spot correction" to the data (Drinovec et al., 2015). For AE33, the recommended MAC value of $7.77 \mathrm{~m}^{2} \mathrm{~g}^{-1}$ at $880 \mathrm{~nm}$ was used in this study (Drinovec et al., 2015). For the older model, AE31, a correction algorithm needs to be applied by the user (e.g., Collaud Coen et al., 2010). AE31 determines the BC concentration from the so- 
called attenuation coefficient, and it uses a mass attenuation cross-section value of $16.62 \mathrm{~m}^{2} \mathrm{~g}^{-1}$ at $880 \mathrm{~nm}$.

At DH4, a model AE33 aethalometer was used for the first half of the measurement period (1 January 2017-5 May 2017), and at DH5, the whole data set was measured with an AE33. At these two stations, HSY corrected the eBC concentration by multiplying the concentration by 0.75 according to a comparison with MAAP. At RB2, an older model, AE31, was used. The AE31 was first corrected for the filter loading error by using the correction algorithm suggested by Virkkula et al. (2007). After the filter loading correction, a comparison with MAAP showed that the AE31 data had to be multiplied by 1.08 to acquire similar concentrations (Sect. S3).

\subsection{Measurements of $\mathrm{NO}_{x}$ and $\mathrm{PM}_{2.5}$}

$\mathrm{NO}_{2}$ and the mass of particles smaller than $2.5 \mu \mathrm{m}\left(\mathrm{PM}_{2.5}\right)$ are regulated pollutants based on the air quality directive 2008/50/EC, and therefore they are always measured at the air quality stations. In this study, we used $\mathrm{NO}_{x}\left(\mathrm{NO}+\mathrm{NO}_{2}\right)$ data instead of the regulated $\mathrm{NO}_{2}$ since $\mathrm{NO}_{x}$ describes better the primary traffic emissions. Even though there was much more $\mathrm{NO}_{x}$ and $\mathrm{PM}_{2.5}$ data available compared to eBC data, we used only $\mathrm{NO}_{x}$ and $\mathrm{PM}_{2.5}$ data that were measured parallel to eBC in order to make the comparison and trend analysis systematic.

The $\mathrm{PM}_{2.5}$ concentration was measured with various different instruments, which are listed for each station in Table S1. The instruments were based on four different methods: (1) attenuation of $\beta$ radiation (Thermo model FH 62 I-R), (2) tapered element oscillating microbalance (TEOM; Thermo different models), (3) optical detection (Grimm 180), and (4) collecting the particles in a cascade impactor and manually weighing the collected particles. The instruments, which apply methods $1-3$, measure the concentration continuously. At RB2, where the $\mathrm{PM}_{2.5}$ concentration was measured by collecting the particles in a cascade impactor and weighing the collected particles about three times a week so the time interval of these measurements varied from 2 to 3 days. To compare the $\mathrm{PM}_{2.5}$ measurements to $\mathrm{BC}$ concentration at $\mathrm{RB} 2$, the $\mathrm{PM}_{2.5}$ concentration was interpolated to match the timestamps of the eBC measurements.

$\mathrm{NO}_{x}$ mass concentration $\left[\mathrm{NO}_{x}\right]$ was derived from the measurements of $\mathrm{NO}$ and $\mathrm{NO}_{2}$ so that

$\left[\mathrm{NO}_{x}\right]=1.533 \cdot[\mathrm{NO}]+\left[\mathrm{NO}_{2}\right]$

The mass concentration of $\mathrm{NO}$ and $\mathrm{NO}_{2}$ was measured by instruments which are based on the chemiluminescence method. The instruments used at each station are listed in Table S1.

\subsection{Meteorological measurements}

The meteorological station measuring wind direction (WD), wind speed (WS), temperature $(T)$, pressure $(p)$, relative humidity $(\mathrm{RH})$, and precipitation was located on a rooftop (78 m a.s.1.) close to central Helsinki (Fig. 1). In this study, we used the measurements of meteorological parameters conducted at the rooftop station to represent the meteorological conditions of all stations located in the HMA. We also included data of the mixing height $(\mathrm{MH})$ for southern Finland. The MH was calculated by MPP-FMI, a meteorological preprocessing model developed by the FMI (Karppinen et al., 2000).

\subsection{Data processing}

The data quality was assured by the data producer, and invalid data were omitted from further analysis. The concentrations were converted to ambient outdoor temperature and to normal atmospheric pressure $(1013.25 \mathrm{hPa})$. In this study, we used $1 \mathrm{~h}$ averages for all the variables (the only exception is the $\mathrm{PM}_{2.5}$ data at RB2). The hourly mean values were calculated if the hour had at least $75 \%$ valid data. The hour of day always refers to the local time (note that winter and summer times are used in Finland), and the time stamp of the measurements is reported in the middle of the averaging period.

\subsection{Trend analysis}

We used the seasonal Mann-Kendall test and Sen's slope estimator (Gilbert, 1987) in determining the statistical significance and the slopes of the long-term trends. The MannKendall test and Sen's slope estimator are non-parametric statistical methods which allow missing data points. The method determines the trends for each season (here we used months) separately and tests if the trends for different seasons are homogeneous. We used monthly median values in the trend analysis, and we required at least $14 \mathrm{~d}$ of valid data for each month; otherwise the month was not taken into account in the trend analysis. A similar analysis has been used in various trend studies (e.g., Collaud Coen et al., 2007, 2013; Li et al., 2014; Zhao et al., 2017).

\section{Results and discussion}

\subsection{Spatial variation}

The statistics of eBC, $\mathrm{PM}_{2.5}$, and $\mathrm{NO}_{x}$ concentrations from each site are presented in Fig. 2. The figure includes all the data, and the statistics were determined by using the $1 \mathrm{~h}$ mean values. Figure 2 shows that the arithmetic mean values differed from the median values, which means that the data of the air pollutants were not normally distributed at any station and that the data were skewed to the right (i.e., small concen- 

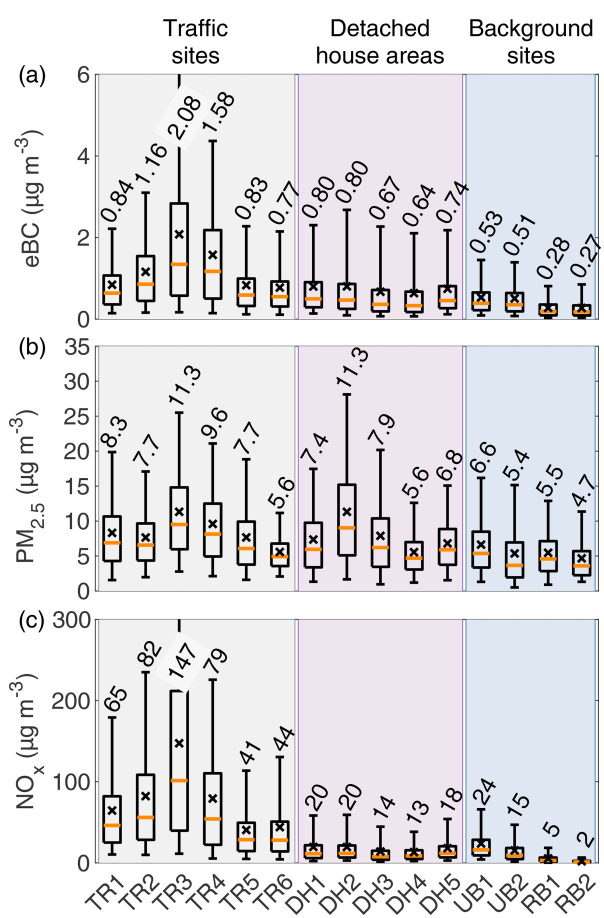

Figure 2. Statistics of the (a) eBC, (b) $\mathrm{PM}_{2.5}$, and (c) $\mathrm{NO}_{x}$ concentrations at each station. The boxplots are presented for $1 \mathrm{~h}$ mean values. The orange line in the middle of each box represents the median, the edges of the boxes represent the 25 th and 75th percentiles, and the whiskers represent the 5th and 95th percentiles. The black cross is the arithmetic mean, and its numerical value is reported above each box. The background color represents the station type: gray for traffic sites (TRs), purple for the detached housing sites (DH), and blue for the background sites (UB for urban and RB for regional background). The 75th percentiles of the eBC and $\mathrm{NO}_{x}$ concentration at TR3, which are not visible at the figure, were 6.7 and $440 \mu \mathrm{g} \mathrm{m}^{-3}$, respectively.

trations occurred more often, and therefore the median values were smaller than the means).

As expected, the highest mean eBC concentrations were observed at the TR sites where the mean eBC concentration varied from 0.77 to $2.08 \mathrm{\mu g} \mathrm{m}^{-3}$ (at TR6 and TR3, respectively). At the $\mathrm{DH}$ sites, the mean $\mathrm{eBC}$ concentration varied from 0.64 to $0.80 \mu \mathrm{g} \mathrm{m}^{-3}$, which were rather similar mean values as observed at TR1, TR5, and TR6 $(0.84,0.83$, and $0.77 \mu \mathrm{g} \mathrm{m}^{-3}$, respectively). At the UB sites, the mean eBC concentrations were around $0.52 \mu \mathrm{g} \mathrm{m}^{-3}$, which was clearly lower than at the TR and DH sites. The lowest mean eBC concentrations, which were around $0.27 \mu \mathrm{g} \mathrm{m}^{-3}$, were observed at the RB sites that had no local BC sources in the vicinity.

Previous studies have shown that in addition to the traffic count, the BC concentration near traffic lines depends on various factors: the distance to the traffic lines (Enroth et al., 2016; Massoli et al., 2012; Zhu et al., 2002), the speed limit (Lefebvre et al., 2011), and the fraction of heavy-duty vehicles (Clougherty et al., 2013; Weichenthal et al., 2014). The surrounding buildings, vegetation, and the wind conditions affect the dilution and therefore the $\mathrm{BC}$ concentrations as well (Abhijith et al., 2017; Brantley et al., 2014; Pirjola et al., 2012). Also, nearby intersections may affect the BC concentrations if they induce traffic buildups; $\mathrm{BC}$ emissions from vehicles that accelerate are higher than the emissions from a steadily moving vehicle (Imhof et al., 2005).

The abovementioned factors are probably the reason for the relatively big differences between the different TR stations and explain, for example, why the eBC concentration at TR3 was notably higher than at the other TR sites. TR3 was located in a street canyon right next to a very busy traffic line. According to Table 2, the traffic count on the closest street next to TR3 was around 44400 vehicles per weekday and the fraction of heavy-duty vehicles was $14 \%$. The traffic count and fraction of heavy-duty vehicles was higher than, for example, on the street next to TR1 or on the street next to TR2. The area around TR3 also consisted of a few busy intersections, and the location in a street canyon probably increased the $\mathrm{eBC}$ concentrations even further.

The effects of total traffic count and traffic count of heavyduty vehicles (HD) on the eBC concentration were studied in more detail in the Supplement (Fig. S9), in which the annual mean eBC concentrations were compared against the estimated weekday traffic counts of all vehicles and of HD vehicles on the nearest street or road. The annual means of eBC concentration correlated better with the number of HD vehicles passing the station $(R=0.82)$ than with the total traffic count $(R=0.71)$. In general, the number of HD vehicles passing TR1, TR5, and TR6 per day was low compared to TR2, TR3, and TR4, and this was also seen in the mean concentration of $\mathrm{eBC}$, which was the highest for the TR2-TR4. This result was expected since the BC emissions from HD vehicles are higher compared to light-duty vehicles (Imhof et al., 2005).

The distance from the stations to the edge of the nearest street varied, which has an effect on the measured eBC concentration (Massoli et al., 2012; Zhu et al., 2002). A study by Enroth et al. (2016) estimated that eBC concentration decreased by $50 \%$ at $33 \mathrm{~m}$ distance from the road. TR2 and TR3, where we observed rather high concentrations, were located right next to the street (in a $0.5 \mathrm{~m}$ distance), whereas the other stations had a longer distance to the nearest street $(3-20 \mathrm{~m})$. Previous studies have also shown that tall trees in street canyons may deteriorate the air quality by preventing dispersion (Abhijith et al., 2017), and this may also have affected the higher measured concentrations at TR2 and TR3. On Mäkelänkatu street, which is next to TR2, there are two lines of trees framing the tram lines in the middle of the street (Fig. S3b), and on Mannerheimintie street, which is next to TR3, there are trees planted between the traffic lines and pavements (Fig. S3c).

Compared to the HMA, higher concentrations of eBC have been reported at other urban areas in Europe. For ex- 
ample, Sun et al. (2019) reported median values of 2.0, 0.9 , and $0.4 \mu \mathrm{g} \mathrm{m}^{-3}$ at several German TR, UB, and RB sites, respectively, measured during 2009-2018. Singh et al. (2018) reported on average eBC concentrations of 1.83 and $1.34 \mu \mathrm{g} \mathrm{m}^{-3}$ measured at several urban center and UB sites in the United Kingdom during 2009-2011. Krecl et al. (2017) observed a mean eBC concentration of $2.1 \mu \mathrm{g} \mathrm{m}^{-3}$ at a street canyon site in Stockholm during weekdays in spring 2013. Becerril-Valle et al. (2017) reported mean eBC values of $3.7 \mu \mathrm{g} \mathrm{m}^{-3}$ at a TR site and $2.33 \mu \mathrm{g} \mathrm{m}^{-3}$ at a UB site measured in Madrid in 2015. The BC concentrations reported by other studies at different environments are higher than the $\mathrm{eBC}$ concentrations measured at corresponding environments in the HMA. Already the concentrations at the RB sites are lower than those measured at other European sites. Generally, the air quality in the HMA and in southern Finland was good. Finland is isolated from the more populated continental Europe by the Baltic Sea, and therefore long-range pollution from the more polluted continental area affects southern Finland less. Due to its coastal location, the HMA is affected by the sea breeze, and the air is therefore well diluted. Compared to other European metropolitan areas, the HMA is small and the area is not as densely populated as many other European capital areas.

In addition to $\mathrm{eBC}$, we also studied the variations in $\mathrm{PM}_{2.5}$ and $\mathrm{NO}_{x}$, presented in Fig. $2 \mathrm{~b}$ and c, respectively. The spatial variation in $\mathrm{NO}_{x}$ was partly similar to that of $\mathrm{eBC}$; the highest concentrations were measured at the TR sites and the lowest at the RB sites. At the TR sites, the mean concentrations varied between 44 and $147 \mu \mathrm{g} \mathrm{m}^{-3}$ (at TR5 and TR3, respectively), and the variation between the stations was rather similar to the variation in $\mathrm{eBC}$. Like $\mathrm{BC}, \mathrm{NO}_{x}$ is highly dependent on the traffic-related parameters, such as the traffic count, the fraction of heavy traffic, the speed limit, etc., which explains the similar variation observed. For the RB sites, however, the mean $\mathrm{NO}_{x}$ (around $2 \mu \mathrm{g} \mathrm{m}^{-3}$ ) was relatively low compared to eBC at RB sites. Another difference to eBC was that the $\mathrm{NO}_{x}$ concentration at the $\mathrm{DH}$ sites was relatively lower, which was expected since the $\mathrm{NO}_{x}$ emissions from residential wood combustion are low. The correlations between $\mathrm{eBC}$ and $\mathrm{NO}_{x}$ concentrations at each station are presented in Fig. S8a. As the likeness in the spatial variability already suggested, the eBC and $\mathrm{NO}_{x}$ had rather similar sources, and therefore they were expected to correlate. The correlation coefficient $(R)$ between these variables was the highest at the TR stations $(0.80 \leq R \leq 0.90)$ and lower at the DH stations $(0.63 \leq R \leq 0.73)$. At the background sites, the correlation coefficient varied more $(0.55 \leq R \leq 0.83)$.

For $\mathrm{PM}_{2.5}$, there were not as clear patterns between different station categories as there were for $\mathrm{eBC}$ and $\mathrm{NO}_{x}$. At the TR sites, the mean $\mathrm{PM}_{2.5}$ concentration varied from 5.6 to $11.3 \mu \mathrm{g} \mathrm{m}^{-3}$ (at TR6 and TR3, respectively), and at the DH sites, the variation was rather similar: from 5.6 to $11.3 \mu \mathrm{g} \mathrm{m}^{-3}$ (at DH4 and DH2, respectively). The mean concentration of $\mathrm{PM}_{2.5}$ at the background sites was not as clearly

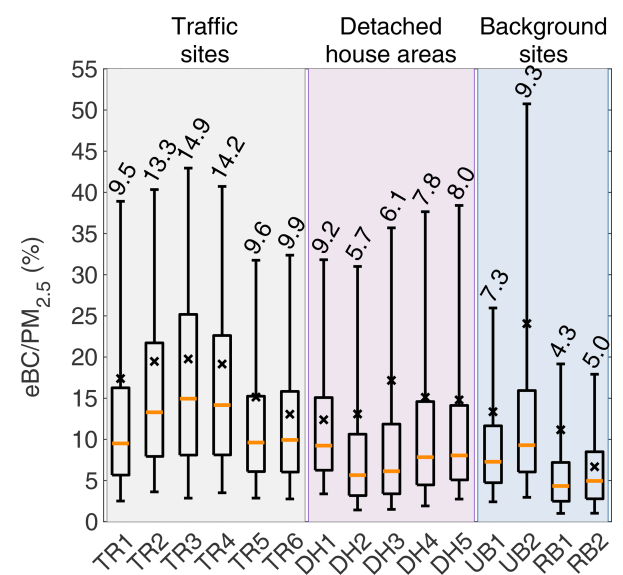

Figure 3. Statistics of eBC/PM 2.5 fraction at each station. The explanation for the markers is the same as in Fig. 2, except here the values reported above each box are the median values.

lower as it was for eBC and $\mathrm{NO}_{x}$. These results show that $\mathrm{PM}_{2.5}$ did not depend on local primary pollution sources as much as eBC or $\mathrm{NO}_{x}$ did. $\mathrm{PM}_{2.5}$ includes all different kinds of aerosol particles, especially secondary aerosol, which may be anthropogenic or biogenic in origin. In this size range, non-anthropogenic particles (e.g., secondary particles of biogenic origin; Dal Maso et al., 2005) are also contributing. The differences in the sources of $\mathrm{eBC}$ and $\mathrm{PM}_{2.5}$ concentrations were also seen in the correlation between these two variables; the $R$ between these two variables at different stations were notably lower $(0.36 \leq R \leq 0.67)$ than the $R$ between $\mathrm{eBC}$ and $\mathrm{NO}_{x}$ concentrations (Fig. S7b).

The fraction of eBC in the $\mathrm{PM}_{2.5}$ is shown in Fig. 3. The eBC was measured mostly in $\mathrm{PM}_{1}$, but since most of the $\mathrm{BC}$ particles are smaller than $1 \mu \mathrm{m}$ in diameter, the difference between the cut-off diameters should not have a big effect on the results (e.g., Enroth et al., 2016). The higher eBC/PM 2.5 ratio indicates that there was a larger fraction of $\mathrm{PM}$ sources related to combustion. The highest median $\mathrm{eBC} / \mathrm{PM}_{2.5}$ ratio was observed at the TR sites where the fraction of $\mathrm{eBC}$ varied from $10 \%$ to $15 \%$. The second highest median ratios were observed at the DH sites and at UB1 where the ratios varied from $5 \%$ to $9 \%$. At the RB sites, the median fractions were the smallest: about $5 \%$.

The results of the spatial variation showed that $\mathrm{eBC}$ concentration and $\mathrm{eBC} / \mathrm{PM}_{2.5}$ ratio depended greatly on the distance to the pollution sources, which were, in this case, traffic and wood combustion. The $\mathrm{NO}_{x}$ was very dependent on the distance to the traffic sources only since $\mathrm{NO}_{x}$ concentration was not significantly affected by residential wood combustion. Since the $\mathrm{PM}_{2.5}$ has various sources and generally high background levels, it was the component least dependent on the contribution of the local sources.

Figures 2 and 3 include all the data that were collected from 2009 to 2018, whereby the sizes of the data sets at each 
station differed. Therefore, the year-to-year variation caused by the meteorological conditions and changes in the emission rates might have affected the results of spatial variability especially at sites that contained only 1 year of data (all DH sites and TR4).

At DH4, DH5, and RB2, at least part of the measurements were conducted by an aethalometer. The aethalometer measured the eBC at $880 \mathrm{~nm}$, which is a longer wavelength than MAAP operated at $(637 \mathrm{~nm})$. This could have caused some difference in the measured eBC concentration in the presence of so-called brown carbon. Brown carbon is organic material, which absorbs light especially at short wavelengths (Andreae and Gelencsér, 2006). However, since the organic carbon absorbs light mainly at wavelengths below $600 \mathrm{~nm}$ (Kirchstetter et al., 2004), the difference between the MAAP and aethalometer wavelengths should not cause a notable effect on the observed $\mathrm{eBC}$ concentration.

As mentioned in Sect. 2.2, we applied constant mass absorption cross-section (MAC) values to convert the optically measured absorption data to $\mathrm{eBC}$ concentration. However, the MAC may vary depending on the chemical composition, shape, and the mixing state of the PM. The MAC increases for aged BC particles as the BC particles get coated with a scattering or slightly absorbing coating which acts as a lens increasing the absorption of the BC core (Lack and Cappa, 2010; Yuan et al., 2020). At TR sites, the freshly emitted BC particles from local traffic probably have no coating on the particles, but at the remote sites, however, particles are carried over longer distances, and the observed $\mathrm{BC}$ at these sites is more aged and likely more coated. Therefore, it is probable that the real MAC at the background sites was higher compared to TR sites. If the differences in the MAC values were taken into account, it could possibly increase the difference between the traffic and background sites. The source of the BC may also have an effect on the MAC, but, for example, Yuan et al. (2020) and Zotter et al. (2017) did not observe a notable difference between the MAC for particles originating from traffic or wood combustion. In addition to spatial variation, the MAC can also vary temporally, which could affect the observed seasonal and diurnal variations and trends (presented in Sect. 3.2) as well. However, determining the variations in MAC would require extensive long-term measurements of the chemical composition of the BC particles in different environments, and therefore further analysis of the effect of MAC is omitted here.

\subsection{Temporal variation}

\subsubsection{Long-term trends}

Table 1 already showed that the annual eBC mean values had seemingly decreased. To see if the decreasing $\mathrm{eBC}$ trend had a statistical significance, we applied the seasonal MannKendall test (see Sect. 2.4.1) to the data sets that were at least 4 years long (TR1, TR2, RB2, and UB1). Even though

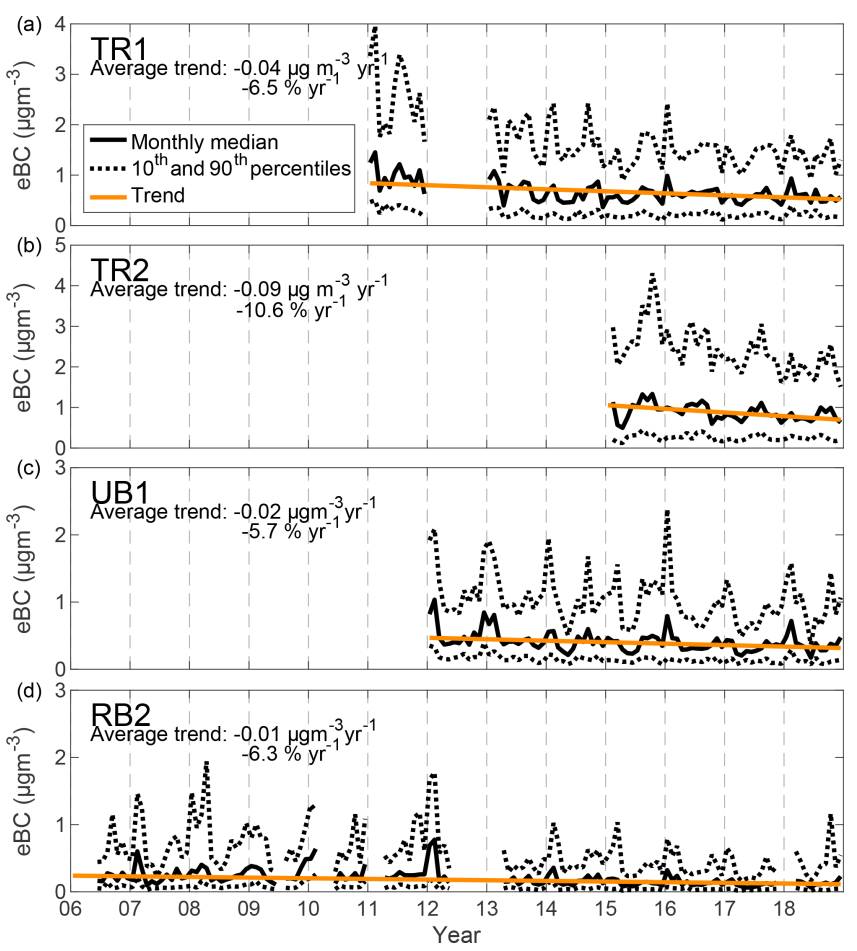

Figure 4. Time series and trends in eBC concentration at TR1, TR2, UB1, and RB2. The solid black line represents the monthly medians, the dashed lines represent the 10th and 90th monthly percentiles, and the orange line is the fitted long-term trend.

there were 4 years of measurements at UB2, the station was omitted from the trend analysis since the data availability at UB2 in 2016-2017 was not good enough. The seasonal Mann-Kendall test was applied to monthly medians values which are presented in Fig. 4 for the eBC concentration at TR1, TR2, UB1, and RB2. We could not apply the trend analysis to any of the DH stations since none of the DH stations had more than 1 year of eBC measurements.

A statistically significant ( $p$ value $<0.05$ ) decreasing trend was observed for all of the stations included in the trend analysis (TR1, TR2, UB1, and RB2) as shown in Fig. 4 and in Table 3. The smallest absolute decrease was observed at the background stations UB1 and RB2, for which the slopes of the trends were -0.02 and $-0.01 \mu \mathrm{g} \mathrm{m}^{-3} \mathrm{yr}^{-1}$, respectively. At TR1, the concentration decreased more rapidly by $-0.04 \mu \mathrm{g} \mathrm{m}^{-3} \mathrm{yr}^{-1}$, and at TR2, the decrease was even greater: $-0.09 \mu \mathrm{g} \mathrm{m}^{-3} \mathrm{yr}^{-1}$. In addition to the absolute trend, we also determined the relative trends by dividing the absolute slope of the trend by the overall median concentration. At TR1, UB1, and RB2, the relative trends were rather similar: $-6.4 \% \mathrm{yr}^{-1},-5.9 \% \mathrm{yr}^{-1}$, and $-6.3 \% \mathrm{yr}^{-1}$, respectively. At TR2, the decrease was relatively steeper: $-10.4 \% \mathrm{yr}^{-1}$.

One possible cause for the decreased pollution concentrations could have been the changes in the meteorological parameters that affect the dilution. Teinilä et al. (2019) re- 
Table 3. Results of the trend analysis of the eBC, $\mathrm{PM}_{2.5}$, and $\mathrm{NO}_{x}$ concentrations. The values without brackets are the absolute trends (in units of $\mu \mathrm{g} \mathrm{m}^{-3} \mathrm{yr}^{-1}$ ), the values in the square brackets are the 5th and 95th uncertainty limits of the trend (in units of $\mu \mathrm{g} \mathrm{m}{ }^{-3} \mathrm{yr}^{-1}$ ), and the bracketed values are the relative trends (in units of $\% \mathrm{yr}^{-1}$ ). The values for $\mathrm{PM}_{2.5}$ at TR2 are italicized since they were statistically not significant $(p$ value $=0.05)$.

\begin{tabular}{lrrrr}
\hline Station & $\mathrm{eBC}\left(\mu \mathrm{g} \mathrm{m}^{-3} \mathrm{yr}^{-1}\right)$ & $\mathrm{PM}_{2.5}\left(\mu \mathrm{g} \mathrm{m}^{-3} \mathrm{yr}^{-1}\right)$ & $\mathrm{NO}_{x}\left(\mu \mathrm{g} \mathrm{m}^{-3} \mathrm{yr}^{-1}\right)$ & Measurement years \\
\hline TR1 & -0.04 & -0.24 & -3.11 & 2011, \\
& {$[-0.06 ;-0.02]$} & {$[-0.38 ;-0.01]$} & {$[-4.18 ;-1.87]$} & $2013-2018$ \\
& $\left(-6.5 \% \mathrm{yr}^{-1}\right)$ & $\left(-3.7 \% \mathrm{yr}^{-1}\right)$ & $\left(-7.1 \% \mathrm{yr}^{-1}\right)$ & \\
\hline TR2 & -0.09 & -0.46 & -11.00 & $2015-2018$ \\
& {$[-0.11 ;-0.05]$} & {$[-0.71 ; 0.02]$} & {$[-12.47 ;-8.70]$} & \\
& $\left(-10.6 \% \mathrm{yr}^{-1}\right)$ & $\left(-7.1 \% r^{-1}\right)$ & $\left(-19.7 \% \mathrm{yr}^{-1}\right)$ & \\
\hline UB1 & -0.02 & -0.20 & -0.80 & $2012-2018$ \\
& {$[-0.03 ;-0.01]$} & {$[-0.34 ;-0.05]$} & {$[-1.08 ;-0.50]$} & \\
\hline RB2 & $\left(-5.7 \% \mathrm{yr}^{-1}\right)$ & $\left(-3.9 \% \mathrm{yr}^{-1}\right)$ & $\left(-5.0 \% \mathrm{yr}^{-1}\right)$ & \\
& {$[-0.01 ;-0.01]$} & {$[-0.18 ;-0.03]$} & {$[-0.09 ;-0.03]$} & \\
& $\left(-6.3 \% \mathrm{yr}^{-1}\right)$ & $\left(-2.6 \% \mathrm{yr}^{-1}\right)$ & $\left(-4.9 \% \mathrm{yr}^{-1}\right)$ & \\
\hline
\end{tabular}

ported that in the HMA, the two most important meteorological parameters that affected the $\mathrm{PM}_{1}$ concentrations were wind speed (WS) and temperature ( $T$ ); Järvi et al. (2008) observed that of the meteorological parameters, the WS and mixing height $(\mathrm{MH})$ affected the $\mathrm{BC}$ concentration the most. The highest concentrations were observed at low WS and $\mathrm{MH}$ conditions and when the $T$ was either very high in summer or very low in winter, which indicates stable and stagnant meteorological conditions. Also, a temperature decrease during colder periods could increase the emissions from residential wood combustion. Therefore, in addition to $\mathrm{BC}$, we ran the trend analysis for the time series of WS, $T$, and $\mathrm{MH}$ (time series in Fig. S1). However, we did not observe statistically significant trends for any of these parameters. We also studied the trends for the different seasons separately to see, for example, if the temperatures had increased in the summer months or decreased in winter months, but this analysis did not yield statistically significant trends either. Therefore, it is likely that the decreasing trends in the $\mathrm{eBC}$ concentration can not be explained by the meteorological factors.

To see how the decrease in $\mathrm{eBC}$ concentrations compared to the trends in other air pollutants, we conducted the trend analysis also for the $\mathrm{PM}_{2.5}$ and $\mathrm{NO}_{x}$ data. The resulting trends are also presented in Table 3. The only parameter for which we did not observe a statistically significant decreasing trend was $\mathrm{PM}_{2.5}$ at TR2 ( $p$ value $=0.05$ ). The relative trends varied from station to station, but a common trait was that the concentrations of $\mathrm{eBC}$ and $\mathrm{NO}_{x}$ decreased relatively faster than the concentration of $\mathrm{PM}_{2.5}$. The trends in $\mathrm{NO}_{x}$ concentration varied from $-19.7 \% \mathrm{yr}^{-1}$ (TR3) to $-4.9 \% \mathrm{yr}^{-1}$ (RB2), and the trends in $\mathrm{PM}_{2.5}$ concentration varied from $-3.9 \% \mathrm{yr}^{-1}$ (UB1) to $-2.6 \% \mathrm{yr}^{-1}$ (RB2). Since there was a notable decrease in the eBC concentration at TR3 between the years 2010 and 2015 (Table 1), the trend at TR3 was also studied, which is presented in Sect. S5. The analysis showed that the concentrations of $\mathrm{eBC}, \mathrm{NO}_{x}$, and $\mathrm{PM}_{2.5}$ decreased about $-12.2 \% \mathrm{yr}^{-1},-8.2 \% \mathrm{yr}^{-1}$, and $-5.6 \% \mathrm{yr}^{-1}$, respectively. Also at TR3, the $\mathrm{PM}_{2.5}$ concentration decreased relatively the slowest.

Compared to $\mathrm{PM}_{2.5}$, the concentrations of eBC and $\mathrm{NO}_{x}$ were more sensitive to the changes in the traffic since they are more dependent on the local sources than $\mathrm{PM}_{2.5}$, as discussed in Sect. 3.1. Therefore, the greater decrease in eBC and $\mathrm{NO}_{x}$ concentrations indicated that especially the emissions from traffic had decreased. Since $\mathrm{PM}_{2.5}$ is not as sensitive to changes in primary traffic-related emissions, it explains why the slope of the trend for $\mathrm{PM}_{2.5}$ was relatively smaller than that of eBC and $\mathrm{NO}_{x}$. In other words, since the pollutant emissions from traffic sources have generally decreased, it clearly affected the trends in $\mathrm{eBC}$ and $\mathrm{NO}_{x}$ which are originating from local traffic sources but to a lesser extent the trend in $\mathrm{PM}_{2.5}$. Even though the decrease in local traffic emissions was the probable explanation for the decreasing trends especially at the TR and UB sites, changes in the long-range transported pollution likely affected the trends as well. Statistically significant trends were observed also at $\mathrm{RB} 2$, indicating that the long-range transported pollution and the emissions in the regional area had also decreased.

For eBC and $\mathrm{NO}_{x}$, it is difficult to say which one of the pollutants decreased at a faster rate. Their relative decreases were rather similar at TR1, UB1, and RB2. At TR2, there was a large difference and $\mathrm{NO}_{x}$ seemed to decrease at double the rate compared to $\mathrm{eBC}$, which could be caused, for example, by the fast renewal of the city bus fleet. According to the Helsinki Regional Transport Authority (HSL), in 2015 , about $17 \%$ of the HSL buses were Euro VI, and in 

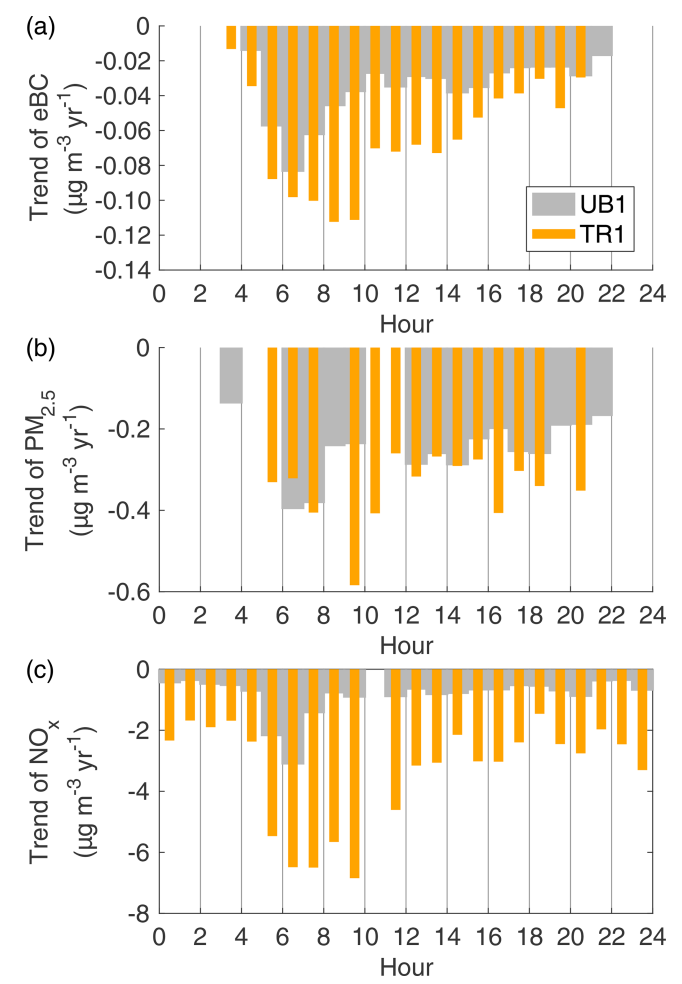

Figure 5. Annual trends for the hourly data. Here, only data from weekdays were used. None of the pollutants had a positive trend for any time of the day.

2018, the fraction had increased to about $50 \%$. A study by Järvinen et al. (2019) showed that moving to Euro VI buses from enhanced environmentally friendly vehicles (EEVs) efficiently decreases the $\mathrm{NO}_{x}$ emissions. However, at TR2, the short time series cause uncertainty in the trends, and, for example, the year-to-year variability caused by the meteorological conditions could cause the apparent decrease in pollutant concentrations.

The trends at TR1 and UB1 were investigated in more detail since these stations had the longest time series and they were located closer to local sources in the HMA. To see if the traffic-related emissions affected the trends, the trend analysis was conducted separately for each hour so that the monthly median was determined for each hour of the day. Only the data from weekdays were included in the analysis. This trend analysis revealed that there were clear decreases in the $\mathrm{eBC}$ and $\mathrm{NO}_{x}$ concentrations around the morning rush hour, as shown in Fig. 5a and c. The trend in the eBC concentration had a distinctive diurnal cycle in general so that the decrease was more prominent during morning and day, and actually there was no statistically significant trend during nighttime (22:00-03:00 EET). A similar diurnal pattern was observed for the $\mathrm{PM}_{2.5}$ as well; however, the pattern was not as well defined as for the eBC. At TR1, the $\mathrm{PM}_{2.5}$ data between 08:00 and 09:00 and 21:00 and 22:00 were not included in the trend analysis due to technical issues caused by a disturbance of the air conditioning. In principle, the diurnal trends indicated that the primary emissions from traffic have decreased most prominently, i.e., changes in traffic regulations and technological advancements have especially decreased the eBC and $\mathrm{NO}_{x}$ emissions.

According to the report about traffic in Helsinki, the traffic volume in Helsinki increased a bit, by $0.4 \% \mathrm{yr}^{-1}$, during the period 2006-2016 (Helsinki, 2017, in Finnish only). However, in general, the number of vehicles entering and exiting the city center (represented by TR1) decreased by $1.5 \% \mathrm{yr}^{-1}$, and the number of vehicles entering and exiting the central urban area (represented by TR2, TR3, and UB1) decreased by $0.8 \% \mathrm{yr}^{-1}$ during the same period, which obviously decreases the emissions from traffic. The decreases in traffic rates were especially observed in the northwestern part of the central urban area (e.g., Fig. S10c), which probably affected the trends observed at TR3. However, on Mäkelänkatu, which is the main street next to TR2 where decreasing trends were also observed, there was no clear decrease in the traffic rate (Fig. S10f).

Since the traffic rates did not decrease at all of the stations, it can be concluded that the decreasing trends were due to the renewal of vehicle and bus fleet, as well as cleaner renewable fuels which have been shown to decrease both $\mathrm{BC}$ and $\mathrm{NO}_{x}$ emissions (Järvinen et al., 2019; Pirjola et al., 2019; Timonen et al., 2017). The exhaust particle number of diesel and gasoline vehicles has been regulated efficiently in order to reduce the traffic emissions. The regulations have enforced the use of diesel particulate filters (DPFs) in new diesel passenger cars and heavy-duty diesel vehicles, reducing their BC and PM emissions even more than $90 \%$ and up to $99 \%$ when compared to the diesel vehicles without a DPF (Bergmann et al., 2009; Preble et al., 2015). Also, the increased use of biofuels and gas as vehicle fuels increased the share of electric vehicles, and improvements in fuel economy in internal combustion engines affected the observed trends. For example, the increase in fuel injection pressure in diesel combustion can improve the fuel economy of engines and simultaneously decrease the BC emissions of engines (Lähde et al., 2011).

Decreases in the eBC concentration (or absorption coefficient) have also been observed in the Finnish arctic (Dutkiewicz et al., 2014; Lihavainen et al., 2015). In general, declining trends in atmospheric aerosol particle number concentration and particulate material have been observed in various different types of environments in Europe (Asmi et al., 2013). Similar results for the trend in eBC concentration have been reported in several cities and countries in Europe. In Stockholm, Sweden, Krecl et al. (2017) reported about a $60 \%$ reduction in $\mathrm{eBC}$ concentration in a busy street canyon between the years 2006 and 2013 (i.e., $-7.5 \% \mathrm{yr}^{-1}$ ). Singh et al. (2018) observed a statistically significant decreasing trend in $\mathrm{eBC}$ concentration at five measurements stations which operated during 2009-2016 and were located in different types of environments in the United Kingdom. The trends varied from $-0.09 \mu \mathrm{g} \mathrm{m}^{-3} \mathrm{yr}^{-1}\left(-4.7 \% \mathrm{yr}^{-1}\right)$ at an 
UB site to $-0.80 \mu \mathrm{g} \mathrm{m}^{-3} \mathrm{yr}^{-1}\left(-8.0 \% \mathrm{yr}^{-1}\right)$ at a TR station. A trend study based only in London reported on average a $-0.59 \mu \mathrm{g} \mathrm{m}^{-3} \mathrm{yr}^{-1}\left(-11 \% \mathrm{yr}^{-1}\right)$ decrease in eBC concentration at three TR sites for the period 2010-2014 (Font and Fuller, 2016). Kutzner et al. (2018) observed statistically significant decreasing BC (both eBC and elemental carbon) trends for the period of 2005-2014 at several sites in Germany. The trends at TR sites varied from -0.31 to $-0.15 \mu \mathrm{g} \mathrm{m}^{-3} \mathrm{yr}^{-1}$, and the trends at UB sites varied from -0.03 to $-0.02 \mu \mathrm{g} \mathrm{m}^{-3} \mathrm{yr}^{-1}$. Also, a more recent study by Sun et al. (2020) reported decreasing relative trends in eBC in Germany for the period of 2009-2018: from -0.19 to $-0.08 \mu \mathrm{g} \mathrm{m}^{-3} \mathrm{yr}^{-1}$ ( -11.3 to $\left.-5.0 \% \mathrm{yr}^{-1}\right)$, from -0.08 to $-0.03 \mu \mathrm{g} \mathrm{m}^{-3} \mathrm{yr}^{-1}\left(-8.1 \% \mathrm{yr}^{-1}\right.$ to $\left.-2.3 \% \mathrm{yr}^{-1}\right)$, and from -0.03 to $0.00 \mu \mathrm{g} \mathrm{m}^{-3} \mathrm{yr}^{-1}\left(-7.8 \% \mathrm{yr}^{-1}\right.$ to $\left.-3.2 \% \mathrm{yr}^{-1}\right)$ at TR, UB, and RB sites, respectively.

These studies reported higher absolute trends compared to the absolute trends observed in our study, which is probably due to lower eBC concentrations in southern Finland. However, the relative trends were rather similar. Similar to this study, other studies also observed steeper absolute trends at TR and UB sites than at RB sites. Sun et al. (2020) observed similar diurnal eBC trends at TR and UB sites as we did in that the decreasing trends were the highest during the morning rush hour. In addition to eBC, Krecl et al. (2017) also studied the trend in $\mathrm{NO}_{x}$, and Font and Fuller (2016) studied the trend in $\mathrm{PM}_{2.5}$. Contradictory to our study, Krecl et al. (2017) did not observe a decreasing trend in $\mathrm{NO}_{x}$, and Font and Fuller (2016) reported decreasing trends in $\mathrm{PM}_{2.5}$ concentration which were relatively similar to the trends in eBC concentration.

The abovementioned studies, which were conducted in urban environments, suggested that the dominant reason for the decreased BC concentrations were traffic regulations. Krecl et al. (2017) drew a connection between the decreasing eBC concentration and the renewal of the vehicle fleet. Sun et al. (2020), Singh et al. (2018), and Kutzner et al. (2018) proposed that the reductions in $\mathrm{eBC}$ were linked to the local and national air quality policies. Font and Fuller (2016) suspected that the eBC concentration decreased due to effective filters in diesel vehicles.

\subsubsection{Seasonal, weekly, and diurnal variation in BC}

The diurnal variation in $\mathrm{eBC}$ was investigated separately for the cold and the warm seasons. According to Fig. S1, the coldest 5 months typically extended from November to March and the warmest 5 months from May to September. April and October were omitted from this analysis as transition months. The seasonal dependencies for each station separately are presented in Figs. S11 and S12.

The seasonal and diurnal variations in $\mathrm{eBC}$ were rather similar between the stations that belong in the same category (Fig. S13). Instead of studying the variation at each station separately, we determined a mean diurnal variation for differ-
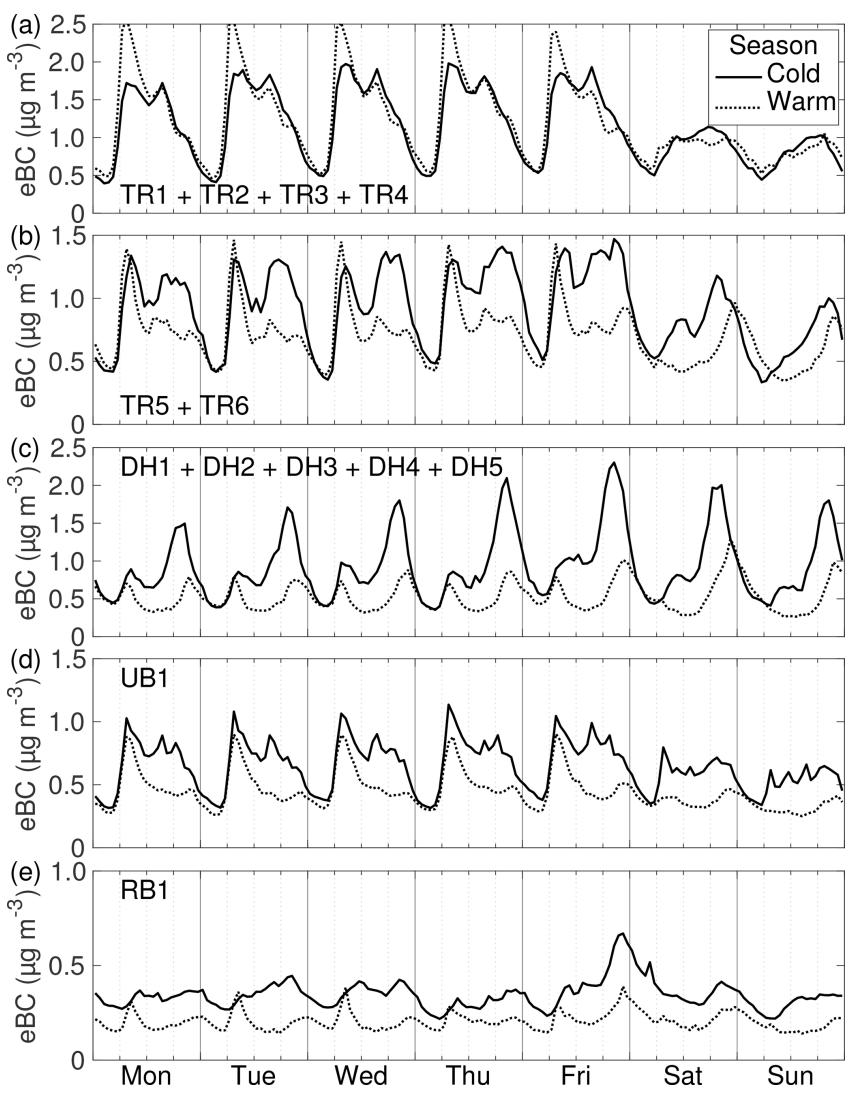

Figure 6. Diurnal variation in eBC for different station categories: (a) traffic sites that were not influenced by wood burning (TR14), (b) traffic sites that were influenced by wood burning (TR5-6), (c) detached housing sites (DH1-5), (d) urban background (UB1), and (e) regional background (RB1). The diurnal variation is determined separately for the cold (from November to March) and warm (from May to September) periods.

ent station categories to study the variation more generally. The figures were plotted by calculating the mean concentration each hour of each day of the week for the cold and the warm seasons separately. All the available data were taken into account when the diurnal variation from different stations were averaged together.

The mean seasonal, weekly, and diurnal variations in eBC for different station categories are presented in Fig. 6. At TR1, TR2, TR3, and TR4 (i.e., TR1-4), the seasonal and diurnal variation was different from TR5 and TR6 (i.e., TR56 ), and therefore the mean diurnal variations for these sets of stations were plotted separately in Fig. 6a-c, which present the mean diurnal variation averaged over all the DH sites. Since UB1 had a notably longer time series compared to UB2, these two time series were not combined, and only the diurnal variation from UB1 is used in Fig. 6d. The diurnal variation at RB1 was also presented without combining it with RB2 data in Fig. 6e. 
Figure 6 shows two common traits observed at all of the TR, DH, and UB sites during both seasons: (1) the eBC concentration peak appeared each weekday morning around 08:00 because of the morning rush hour and (2) the lowest eBC concentrations were measured each day during the night around 03:00 when there were not many anthropogenic activities. In addition to these common trends, each station category had their own traits in the seasonal, weekly, and diurnal variation. We also did a similar variation analysis for the eBC/ $\mathrm{PM}_{2.5}$ ratio presented in Fig. S14. In general, the $\mathrm{eBC} / \mathrm{PM}_{2.5}$ ratio seemed to follow the variation in eBC (i.e., the eBC varies relatively more than $\mathrm{PM}_{2.5}$ ).

At TR1-4, the seasonal variation in eBC was not strong, and in Fig. 6a, the lines for the cold and the warm season follow each other. The lack of seasonal variation in the traffic environment was also observed previously in the HMA (Helin et al., 2018; Teinilä et al., 2019) and elsewhere (Kutzner et al., 2018; Reche et al., 2011). During weekdays, the morning concentration peak of eBC occurred around 08:00 and the afternoon peak around 16:00. The variation in eBC concentration correlated with the diurnal variation in the traffic counts (examples of traffic rates from Mannerheimintie and Mäkelänkatu in Fig. S10). The eBC concentration was notably lower during weekends when the traffic rates were also lower. Järvi et al. (2008) also reported that the nearby traffic rates are the most important factors explaining the variation in eBC concentration at a TR site.

During the warm season at TR1-4 sites, the morning eBC concentration peak was higher during the cold season. Since seasonal variation in the traffic rates was not expected, the observation was probably explained by the variation in WS and $\mathrm{MH}$. When the $\mathrm{MH}$ and WS are higher, the concentrations of air pollutants decrease due to more effective dilution (Järvi et al., 2008; Teinilä et al., 2019). Figure S2 shows that the $\mathrm{MH}$ and WS in the morning (before 09:00) during the cold season were lower than in the warm season. WS and $\mathrm{MH}$ had a clear diurnal cycle in the warm season, but in the cold season, the WS or MH had no variation whatsoever. The lower $\mathrm{MH}$ and WS in morning during the warm season could explain why the eBC concentrations peak during the warm season mornings.

The seasonal variation in $\mathrm{eBC}$ was the most pronounced at the $\mathrm{DH}$ sites where the lowest concentrations occurred in June and July and the highest concentrations in December and January (Fig. S12g-k), which is likely explained by the residential wood combustion during the cold season. At the DH sites, the highest concentrations were measured during the evening (Fig. 6c) when people returned back home and started to warm up their houses and saunas. This was different to other station categories for which the morning concentration peak was higher or similar compared to the afternoon peak. Domestic wood combustion also increased the concentrations during the weekend, and unlike at the TR and UB sites, the eBC concentration at the $\mathrm{DH}$ sites were rather similar compared to the weekdays.
The effect of wood combustion at DH sites was studied by Helin et al. (2018), who applied AE33 data measured at TR2, DH3, and DH4 (note the different names of the sites between our study and the study by Helin et al., 2018) in a source apportionment model suggested by Sandradewi et al. (2008). They reported that on average about $41 \%$ and $46 \%$ of the eBC observed at DH4 and DH5, respectively, originated from wood combustion. The fractions were notably higher than those observed at TR2 (about $15 \%$ ). They also observed higher eBC fractions from wood combustion in the cold season: for example, eBC fractions from wood combustion were $46 \%$ and $35 \%$ at DH3 in winter and summer, respectively. The effect of wood combustion in evenings was also evident in the data by Helin et al. (2018) who observed that eBC from wood combustion increased towards the evening at DH3 and DH4. A comparison between weekdays and weekends at DH3 showed similar eBC concentrations originating from traffic but slightly increased eBC concentrations from wood combustion on the weekend.

The effect of residential wood combustion on the diurnal variation was also observed at TR5-6 (Fig. 6b), which were closer to the detached housing areas than the other TR sites (see Fig. 1). The temporal variation at TR5-6 was a mix between the variation observed at the other traffic sites (TR14) and at the DH sites. At TR5-6, the concentration of eBC was notably higher in the evenings during the cold season compared to the warm season, which is similar to the $\mathrm{DH}$ stations. In addition, the maximum of the afternoon concentration peak occurred around the same time as at the $\mathrm{DH}$ sites. However, the effect of traffic is seen in the afternoon peaks since the peaks grew more rapidly around the afternoon rush hour. The traffic also affected the morning concentration peak, which is similar to the afternoon concentration peak, whereas at the DH sites, the morning peak was notably lower. At TR5-6, the eBC concentration during weekends was lower than during weekdays, which was observed at the other TR sites as well. However, the difference was not as pronounced, which is again due to the effect of wood combustion (e.g., increased eBC concentration during Saturday evening).

In the cold season, the diurnal variation in eBC at UB1 was rather similar to the diurnal variation at TR1-4, with the rush hour peaks occurring in the morning and afternoon (Fig. 6d). During the warm season, however, the afternoon rush hour peak was missing. Also on weekends, the concentrations during the warm season were considerably lower. Since UB1 was not in the vicinity of pollution sources, the effect of dilution, which is governed by meteorological parameters, became more important. In the daytime during the warm season, the pollutants were diluted in the convective and more windy (Fig. S2) boundary layer effectively, whereas during the cold season the pollutants accumulated in the boundary layer if it was shallower and did not grow during the day as much as in the warm season (Pohjola et al., 2004). Also, the transported wood combustion emissions from the $\mathrm{DH}$ areas 
can slightly increase the concentrations during the cold season even closer to the city center (Helin et al., 2018).

At the $\mathrm{RB}$ sites, there was a notable seasonal variation as the $\mathrm{eBC}$ concentrations are higher during the cold season (Fig. S13n-o) since regional wood combustion emissions and long-range transported pollutants also elevate eBC concentrations at background sites in winter (Luoma et al., 2019). The diurnal and weekly variations, however, were not as clear (e.g., Fig. 6e) as there were no anthropogenic activities nearby. Diurnal variation was mainly caused by the variation in the convective boundary layer height that caused mixing and dilution and not by local anthropogenic sources, which is expected for a regional background station.

It is important to note that the measured variation in the eBC concentration was affected by both the BC emissions and the atmospheric processes determining the dilution of the $\mathrm{BC}$. For instance, the diurnal variation in the eBC concentration at a traffic site is affected by the traffic rate on the nearby streets, roads, and highways, but it is affected also by changes in local weather conditions possibly having a diurnal variation. Such atmospheric parameters are, e.g., ambient temperature, prevailing wind direction, wind speed, and height of the boundary layer. Furthermore, especially the ambient temperature can also directly affect the emissions; e.g., slightly higher wintertime morning concentrations in detached housing areas can be due to the effects of ambient temperature or the cold start emissions of passenger cars.

\section{Conclusions}

This study analyzed the time series of atmospheric eBC concentrations in traffic, detached house, urban background, and regional background environments measured in the years 2007-2018 in the Helsinki metropolitan area (HMA) and at one background site outside the HMA. The overall mean eBC concentration varied in the range of 0.77 to $2.08 \mu \mathrm{g} \mathrm{m}^{-3}$ at TR stations, 0.64 to $0.80 \mu \mathrm{g} \mathrm{m}^{-3}$ at $\mathrm{DH}$ stations, and 0.51 to $0.53 \mu \mathrm{g} \mathrm{m}^{-3}$ at UB stations. At the RB sites, the mean eBC concentrations were the lowest, about $0.27 \mu \mathrm{g} \mathrm{m}^{-3}$.

The study highlights the importance of local sources in respect of urban air quality; it shows that the local traffic and residential wood combustion in residential areas formed the main sources of atmospheric eBC in the urban area studied here. The influence of traffic was clearly seen at the traffic stations (TRs) as was the effect of domestic wood combustion at the detached housing sites (DH). At the TR sites, which were located closer to residential areas (TR5-6), the diurnal variation showed signs that the air quality in the area was heavily affected both by traffic and domestic wood burning emissions. The concentrations at the TR sites reached their peak in the weekday mornings and stayed elevated until the afternoon rush hour had passed. In the evening, after the workday, the eBC concentrations reached their maxima at the $\mathrm{DH}$ sites where the residents warmed up their houses partly by wood combustion. At the DH sites, the eBC concentrations did not decrease during the weekend like at the TR sites.

The trend analysis conducted in this study showed statistically significant decreasing trends in atmospheric BC. Decreasing eBC concentration has two positive effects: (1) improved air quality and (2) decreased warming effect on the global climate by light-absorbing aerosols. The absolute trends in eBC concentration were most notable at the TR sites where the trends varied from -0.04 to $-0.09 \mu \mathrm{g} \mathrm{m}^{-3} \mathrm{yr}^{-1}$. At an UB station and at an RB station, the absolute trends were -0.02 and $-0.01 \mu \mathrm{g} \mathrm{m}^{-3} \mathrm{yr}^{-1}$, respectively. The relative trends in eBC concentration varied from $-10.6 \% \mathrm{yr}^{-1}$ to $-5.7 \% \mathrm{yr}^{-1}$, which was rather similar to the relative trends in $\mathrm{NO}_{x}$ concentration which varied from -19.7 to $-4.9 \% \mathrm{yr}^{-1}$. The relative trends in $\mathrm{PM}_{2.5}$, which varied from $-3.9 \% \mathrm{yr}^{-1}$ to $-2.6 \% \mathrm{yr}^{-1}$, did not decrease as rapidly as the trends in eBC and $\mathrm{NO}_{x}$. For the eBC and $\mathrm{NO}_{x}$, the most notable decrease was observed for the morning rush hour times when traffic had the biggest effect on the air quality. The difference between the relative trends in $\mathrm{eBC}, \mathrm{NO}_{x}$, and $\mathrm{PM}_{2.5}$ concentrations, and the most notable decrease in $\mathrm{eBC}$ and $\mathrm{NO}_{x}$ concentrations during the morning rush hour, indicated that especially the emissions from traffic had decreased.

This study suggests that the development in vehicle exhaust particle mitigation has been successful, at least from the viewpoint of $\mathrm{BC}$ and $\mathrm{NO}_{x}$ emissions. With the current development, the pollution concentrations are expected to decrease in the next years as well. In general, the vehicle fleet is renewing, electric and hybrid cars are gaining popularity, and vehicles that run with biofuels or gas are becoming more common. The operator of public traffic in the HMA (HSL) aims to cut more than $90 \%$ of their bus emissions $\left(\mathrm{NO}_{x}, \mathrm{PM}\right.$, $\mathrm{CO}_{2}$ ) by the year 2025 compared to the year 2010, which will improve the air quality especially on the main roads in the HMA where several bus lines operate.

This study also shows the need for the regulation and mitigation of emissions from residential wood combustion, which is, according to the emission inventories, actually the most significant BC source in Finland (Rautalahti and $\mathrm{Ku}-$ piainen, 2016). The research material of this study did not allow for the assessment of long-term trends in DH areas but, in principle, no similar technological changes have been observed in wood combustion as have been implemented in vehicles.

Data availability. All the data presented in this study are open access. The air quality data collected by the HSY are available from their website (https://www.hsy.fi/avoindata, last access: 20 January 2021). The data collected from the SMEAR sites (UB2 and RB2) have been accessed through the Smart-SMEAR online tool (https://smear.avaa.csc.fi/, last access: 20 January 2021; Junninen et al., 2009). 
Supplement. The supplement related to this article is available online at: https://doi.org/10.5194/acp-21-1173-2021-supplement.

Author contributions. KL did the majority of the data analysis and writing of the manuscript. KL was responsible for RB2 BC data; JVN and AK provided the data from the HSY sites; HT, AH, and MA provided the data from UB2; and LK provided the mixing height data. All the coauthors (JVN, MA, FLF, AH, TH, LK, AK, $\mathrm{TR}, \mathrm{HT}, \mathrm{AV}$, and TP) reviewed and commented on the manuscript.

Competing interests. The authors declare that they have no conflict of interest.

Acknowledgements. We appreciate the constructive comments from the editor and the anonymous referees.

Financial support. This research has been supported by the Academy of Finland (grant nos. 307331 and 207537), the ACTRISFinland (grant no. 32927), the Ministry of Economic Affairs and Employment (grant no. AIKO014), Business Finland (grant nos. 528/31/2019 and 6884/31/2018), the European Commission (grant nos. ACTRIS-2 (654109), ERA-PLANET (689443)), the European Commission (grant no. ACTRIS-IMP, 871115), ERA-NET Cofund, and the University of Helsinki (ACTRIS-HY).

Open-access funding was provided by the Helsinki University Library.

Review statement. This paper was edited by Willy Maenhaut and reviewed by three anonymous referees.

\section{References}

Abhijith, K. V., Kumar, P., Gallagher, J., McNabola, A., Baldauf, R., Pilla, F., Broderick, B., Di Sabatino, S., and Pulvirenti, B.: Air pollution abatement performances of green infrastructure in open road and built-up street canyon environments - A review, Atmos. Environ., 162, 71-86, https://doi.org/10.1016/j.atmosenv.2017.05.014, 2017.

Andreae, M. O. and Gelencsér, A.: Black carbon or brown carbon? The nature of light-absorbing carbonaceous aerosols, Atmos. Chem. Phys., 6, 3131-3148, https://doi.org/10.5194/acp-63131-2006, 2006.

Asmi, A., Collaud Coen, M., Ogren, J. A., Andrews, E., Sheridan, P., Jefferson, A., Weingartner, E., Baltensperger, U., Bukowiecki, N., Lihavainen, H., Kivekäs, N., Asmi, E., Aalto, P. P., Kulmala, M., Wiedensohler, A., Birmili, W., Hamed, A., O’Dowd, C., G Jennings, S., Weller, R., Flentje, H., Fjaeraa, A. M., Fiebig, M., Myhre, C. L., Hallar, A. G., Swietlicki, E., Kristensson, A., and Laj, P.: Aerosol decadal trends - Part 2: In-situ aerosol particle number concentrations at GAW and ACTRIS stations, Atmos.
Chem. Phys., 13, 895-916, https://doi.org/10.5194/acp-13-8952013, 2013.

Aurela, M., Saarikoski, S., Niemi, J. V., Canonaco, F., Prevot, A. S. H., Frey, A., Carbone, S., Kousa, A., and Hillamo, R.: Chemical and source characterization of submicron particles at residential and traffic sites in the Helsinki metropolitan area, Finland, Aerosol Air Qual. Res., 15, 1213-1226, https://doi.org/10.4209/aaqr.2014.11.0279, 2015.

Becerril-Valle, M., Coz, E., Prévôt, A. S. H., Močnik, G., Pandis, S. N., de la Campa, A. M. S., Alastuey, A., Díaz, E., Pérez, R. M., and Artíñano, B.: Characterization of atmospheric black carbon and co-pollutants in urban and rural areas of Spain, Atmos. Environ., 169, 36-53, https://doi.org/10.1016/j.atmosenv.2017.09.014, 2017.

Bergmann, M., Kirchner, U., Vogt, R., and Benter, T.: On-road and laboratory investigation of low-level PM emissions of a modern diesel particulate filter equipped diesel passenger car, Atmos. Environ., 43, 1908-1916, https://doi.org/10.1016/j.atmosenv.2008.12.039, 2009.

Brantley, H. L., Hagler, G. S., Deshmukh, P. J., and Baldauf, R. W.: Field assessment of the effects of roadside vegetation on nearroad black carbon and particulate matter, Sci. Total Environ., 468, 120-129, https://doi.org/10.1016/j.scitotenv.2013.08.001, 2014.

Clougherty, J. E., Kheirbek, I., Eisl, H. M., Ross, Z., Pezeshki, G., Gorczynski, J. E., Johnson, S., Markowitz, S., Kass, D., and Matte, T.: Intra-urban spatial variability in wintertime street-level concentrations of multiple combustion-related air pollutants: the New York City Community Air Survey (NYCCAS), J. Expo. Sci. Env. Epid., 23, 232-240, https://doi.org/10.1038/jes.2012.125, 2013.

Collaud Coen, M., Weingartner, E., Nyeki, S., Cozic, J., Henning, S., Verheggen, B., Gehrig, R., and Baltensperger, U.: Long-term trend analysis of aerosol variables at the highalpine site Jungfraujoch, J. Geophys. Res.-Atmos., 112, D13213, https://doi.org/10.1029/2006JD007995, 2007.

Collaud Coen, M., Weingartner, E., Apituley, A., Ceburnis, D., Fierz-Schmidhauser, R., Flentje, H., Henzing, J. S., Jennings, S. G., Moerman, M., Petzold, A., Schmid, O., and Baltensperger, U.: Minimizing light absorption measurement artifacts of the Aethalometer: evaluation of five correction algorithms, Atmos. Meas. Tech., 3, 457-474, https://doi.org/10.5194/amt-3-4572010, 2010.

Collaud Coen, M., Andrews, E., Asmi, A., Baltensperger, U., Bukowiecki, N., Day, D., Fiebig, M., Fjaeraa, A. M., Flentje, H., Hyvärinen, A., Jefferson, A., Jennings, S. G., Kouvarakis, G., Lihavainen, H., Lund Myhre, C., Malm, W. C., Mihapopoulos, N., Molenar, J. V., O’Dowd, C., Ogren, J. A., Schichtel, B. A., Sheridan, P., Virkkula, A., Weingartner, E., Weller, R., and Laj, P.: Aerosol decadal trends - Part 1: In-situ optical measurements at GAW and IMPROVE stations, Atmos. Chem. Phys., 13, 869894, https://doi.org/10.5194/acp-13-869-2013, 2013.

Dal Maso, M., Kulmala, M., Riipinen, I., Wagner, R., Hussein, T., Aalto, P. P., and Lehtinen, K. E. J.: Formation and growth of fresh atmospheric aerosols: eight years of aerosol size distribution data from SMEAR II, Hyytiala, Finland, Boreal Environ. Res., 10, 323-336, 2005.

Dos Santos-Juusela, V., Petäjä, T., Kousa, A., and Hämeri, K.: Spatial-temporal variations of particle number concentrations be- 
tween a busy street and the urban background, Atmos. Environ., 79, 324-333, https://doi.org/10.1016/j.atmosenv.2013.05.077, 2013.

Drinovec, L., Močnik, G., Zotter, P., Prévôt, A. S. H., Ruckstuhl, C., Coz, E., Rupakheti, M., Sciare, J., Müller, T., Wiedensohler, A., and Hansen, A. D. A.: The "dual-spot" Aethalometer: an improved measurement of aerosol black carbon with realtime loading compensation, Atmos. Meas. Tech., 8, 1965-1979, https://doi.org/10.5194/amt-8-1965-2015, 2015.

Dutkiewicz, V. A., DeJulio, A. M., Ahmed, T., Laing, J., Hopke, P. K., Skeie, R. B., Viisanen, Y., Paatero, J., and Husain, L.: Forty-seven years of weekly atmospheric black carbon measurements in the Finnish Arctic: Decrease in black carbon with declining emissions, J. Geophys. Res.-Atmos., 119, 7667-7683, https://doi.org/10.1002/2014JD021790, 2014.

Enroth, J., Saarikoski, S., Niemi, J., Kousa, A., Ježek, I., Močnik, G., Carbone, S., Kuuluvainen, H., Rönkkö, T., Hillamo, R., and Pirjola, L.: Chemical and physical characterization of traffic particles in four different highway environments in the Helsinki metropolitan area, Atmos. Chem. Phys., 16, 5497-5512, https://doi.org/10.5194/acp-16-5497-2016, 2016.

Font, A. and Fuller, G. W.: Did policies to abate atmospheric emissions from traffic have a positive effect in London?, Environ. Pollut., 218, 463-474, https://doi.org/10.1016/j.envpol.2016.07.026, 2016.

Gilbert, R. O.: Statistical methods for environmental pollution monitoring, John Wiley \& Sons, New York, USA, 1987.

Hari, P. and Kulmala, M.: Station for measuring ecosystematmosphere relations, Boreal Environ. Res., 10, 315-322, 2005.

Helin, A., Niemi, J. V., Virkkula, A., Pirjola, L., Teinilä, K., Backman, J., Aurela, M., Saarikoski, S., Rönkkö, T., Asmi, E., and Timonen, H.: Characteristics and source apportionment of black carbon in the Helsinki metropolitan area, Finland, Atmos. Environ., 190, 87-98, https://doi.org/10.1016/j.atmosenv.2018.07.022, 2018.

Hellén, H., Kangas, L., Kousa, A., Vestenius, M., Teinilä, K., Karppinen, A., Kukkonen, J., and Niemi, J. V.: Evaluation of the impact of wood combustion on benzo[a]pyrene (BaP) concentrations; ambient measurements and dispersion modeling in Helsinki, Finland, Atmos. Chem. Phys., 17, 3475-3487, https://doi.org/10.5194/acp-17-3475-2017, 2017.

Helsingin kaupunki/kaupunkiympäristön toimiala (City of Helsinki/Urban environment division): Liikenteen kehitys Helsingissä 2016 (Development of traffic in Helsinki in 2016) Series title: Kaupunkiympäristön julkaisuja, 2017, 61 pp., 2017.

Hienola, A. I., Pietikäinen, J.-P., Jacob, D., Pozdun, R., Petäjä, T., Hyvärinen, A.-P., Sogacheva, L., Kerminen, V.-M., Kulmala, M., and Laaksonen, A.: Black carbon concentration and deposition estimations in Finland by the regional aerosol-climate model REMO-HAM, Atmos. Chem. Phys., 13, 4033-4055, https://doi.org/10.5194/acp-13-4033-2013, 2013.

HSY: Helsingin seudun ympäristöpalvelut (Helsinki Region Services Authority): Tulisijojen käyttö ja päästöt pääkaupunkiseudulla vuonna 2014 (The use of fireplaces and the emissions from small-scale combustion in the Helsinki metropolitan area in 2014) Series title: HSY:n julkaisuja, Helsinki Region Environmental Services Authority, Helsinki, 2/2016, 53 pp., 2016.
HSY: HSY Open data, available at: https://www.hsy.fi/avoindata, last access: 20 January 2021.

Hyvärinen, A.-P., Kolmonen, P., Kerminen, V.-M., Virkkula, A., Leskinen, A., Komppula, M., Hatakka, J., Burkhart, J., Stohl, A., Aalto, P., Kulmala, M., Lehtinen, K. E. J., Viisanen, Y., and Lihavainen, H.: Aerosol black carbon at five background measurement sites over Finland, a gateway to the Arctic, Atmos. Environ., 45, 4042-4050, https://doi.org/10.1016/j.atmosenv.2011.04.026, 2011.

Imhof, D., Weingartner, E., Ordóñez, C., Gehrig, R., Hill, M., Buchmann, B., and Baltensperger, U.: Real-world emission factors of fine and ultrafine aerosol particles for different traffic situations in Switzerland, Environ. Sci. Technol., 39, 8341-8350, https://doi.org/10.1021/es048925s, 2005.

Janssen, N. A. H., Hoek, G., Simic-Lawson, M., Fischer, P., Van Bree, L., Ten Brink, H., Keuken, M., Atkinson, R. W., Anderson, H. R., Brunekreef, B., and Cassee, F. R.: Black carbon as an additional indicator of the adverse health effects of airborne particles compared with $\mathrm{PM}_{10}$ and $\mathrm{PM}_{2.5}$, Environ. Health Perspect., 119, 1691-1699, 10.1289/ehp.1003369, 2011.

Järvi, L., Junninen, H., Karppinen, A., Hillamo, R., Virkkula, A., Mäkelä, T., Pakkanen, T., and Kulmala, M.: Temporal variations in black carbon concentrations with different time scales in Helsinki during 1996-2005, Atmos. Chem. Phys., 8, 1017-1027, https://doi.org/10.5194/acp-8-1017-2008, 2008.

Järvi, L., Hannuniemi, H., Hussein, T., Junninen, H., Aalto, P. P., Hillamo, R., Mäkelä, T., Keronen, P., Siivola, E., Vesala, T., and Kulmala, M.: The urban measurement station SMEAR III: Continuous monitoring of air pollution and surface-atmosphere interactions in Helsinki, Finland, Boreal Environ. Res., 14, 86-109, 2009.

Järvinen, A., Timonen, H., Karjalainen, P., Bloss, M., Simonen, P., Saarikoski, S., Kuuluvainen, H., Kalliokoski, J., Dal Maso, M., Niemi, J. V., and Rönkkö, T.: Particle emissions of Euro VI, EEV and retrofitted EEV city buses in real traffic, Environ. Pollut., 250, 708-716, https://doi.org/10.1016/j.envpol.2019.04.033, 2019.

Junninen, H., Lauri, A., Keronen, P., Aalto, P., Hiltunen, V., Hari, P., and Kulmala, M.: Smart-SMEAR: on-line data exploration and visualization tool for SMEAR stations, available at: https:// smear.avaa.csc.fi/ (last access: 20 January 2021), Boreal Environ. Res., 14, 447-457, 2009.

Karppinen, A., Joffre, S. M., and Kukkonen, J.: The refinement of a meteorological pre-processor for the urban environment, Int. J. Environ. Pollut., 14, 565-572, https://doi.org/10.1504/IJEP.2000.000580, 2000.

Kirchstetter, T. W., Novakov, T., and Hobbs, P. V.: Evidence that the spectral dependence of light absorption by aerosols is affected by organic carbon, J. Geophys. Res.-Atmos., 109, D21208, https://doi.org/10.1029/2004JD004999, 2004.

Krecl, P., Johansson, C., Targino, A. C., Ström, J., and Burman, L.: Trends in black carbon and size-resolved particle number concentrations and vehicle emission factors under real-world conditions, Atmos. Environ., 165, 155-168, https://doi.org/10.1016/j.atmosenv.2017.06.036, 2017.

Krzyzanowski, M., Kuna-Dibbert, B., and Schneider, J.: Health effects of transport-related air pollution, WHO Regional Office Europe, 12 pp., 2005. 
Kutzner, R. D., von Schneidemesser, E., Kuik, F., Quedenau, J., Weatherhead, E. C., and Schmale, J.: Long-term monitoring of black carbon across Germany, Atmos. Environ., 185, 41-52, https://doi.org/10.1016/j.atmosenv.2018.04.039, 2018.

Lack, D. A. and Cappa, C. D.: Impact of brown and clear carbon on light absorption enhancement, single scatter albedo and absorption wavelength dependence of black carbon, Atmos. Chem. Phys., 10, 4207-4220, https://doi.org/10.5194/acp10-4207-2010, 2010.

Lähde, T., Rönkkö, T., Happonen, M., Söderström, C., Virtanen, A., Solla, A., Kytö, M., Rothe, D., and Keskinen, J.: Effect of fuel injection pressure on a heavy-duty diesel engine nonvolatile particle emission, Environ. Sci. Technol., 45, 2504 2509, https://doi.org/10.1021/es103431p, 2011.

Lefebvre, W., Fierens, F., Trimpeneers, E., Janssen, S., Van de Vel, K., Deutsch, F., Viaene, P., Vankerkom, J., Dumont, G., Vanpoucke, C., Mensink, C., Peelaerts, W., and Vliegen, J.: Modeling the effects of a speed limit reduction on traffic-related elemental carbon (EC) concentrations and population exposure to EC, Atmos. Environ., 45, 197-207, https://doi.org/10.1016/j.atmosenv.2010.09.026, 2011.

Lelieveld, J., Evans, J. S., Fnais, M., Giannadaki, D., and Pozzer, A.: The contribution of outdoor air pollution sources to premature mortality on a global scale, Nature, 525, 367, https://doi.org/10.1038/nature15371, 2015.

Li, J., Carlson, B. E., Dubovik, O., and Lacis, A. A.: Recent trends in aerosol optical properties derived from AERONET measurements, Atmos. Chem. Phys., 14, 1227112289, https://doi.org/10.5194/acp-14-12271-2014, 2014.

Lihavainen, H., Hyvärinen, A., Asmi, E., Hatakka, J., and Viisanen, Y.: Long-term variability of aerosol optical properties in northern Finland, Boreal Environ. Res., 20, 526-541, 2015.

Luoma, K., Virkkula, A., Aalto, P., Petäjä, T., and Kulmala, M.: Over a 10-year record of aerosol optical properties at SMEAR II, Atmos. Chem. Phys., 19, 11363-11382, https://doi.org/10.5194/acp-19-11363-2019, 2019.

Massoli, P., Fortner, E. C., Canagaratna, M. R., Williams, L. R., Zhang, Q., Sun, Y., Schwab, J. J., Trimborn, A., Onasch, T. B., Demerjian, K. L., Charles, E., Worsnop, D., and Jayne, J.: Pollution gradients and chemical characterization of particulate matter from vehicular traffic near major roadways: Results from the 2009 Queens College Air Quality Study in NYC, Aerosol Sci. Technol., 46, 1201-1218, https://doi.org/10.1080/02786826.2012.701784, 2012.

Pakkanen, T. A., Kerminen, V.-M., Ojanen, C. H., Hillamo, R. E., Aarnio, P., and Koskentalo, T.: Atmospheric black carbon in Helsinki, Atmos. Environ., 34, 1497-1506, https://doi.org/10.1016/S1352-2310(99)00344-1, 2000.

Petzold, A. and Schönlinner, M.: Multi-angle absorption photometry - a new method for the measurement of aerosol light absorption and atmospheric black carbon, J. Aerosol Sci, 35, 421-441, https://doi.org/10.1016/j.jaerosci.2003.09.005, 2004.

Petzold, A., Ogren, J. A., Fiebig, M., Laj, P., Li, S.-M., Baltensperger, U., Holzer-Popp, T., Kinne, S., Pappalardo, G., Sugimoto, N., Wehrli, C., Wiedensohler, A., and Zhang, X.-Y.: Recommendations for reporting "black carbon" measurements, Atmos. Chem. Phys., 13, 8365-8379, https://doi.org/10.5194/acp13-8365-2013, 2013.
Pirjola, L., Lähde, T., Niemi, J., Kousa, A., Rönkkö, T., Karjalainen, P., Keskinen, J., Frey, A., and Hillamo, R.: Spatial and temporal characterization of traffic emissions in urban microenvironments with a mobile laboratory, Atmos. Environ., 63, 156-167, https://doi.org/10.1016/j.atmosenv.2012.09.022, 2012.

Pirjola, L., Niemi, J. V., Saarikoski, S., Aurela, M., Enroth, J., Carbone, S., Saarnio, K., Kuuluvainen, H., Kousa, A., Rönkkö, T., and Hillamo, R.: Physical and chemical characterization of urban winter-time aerosols by mobile measurements in Helsinki, Finland, Atmos. Environ., 158, 60-75, https://doi.org/10.1016/j.atmosenv.2017.03.028, 2017.

Pirjola, L., Kuuluvainen, H., Timonen, H., Saarikoski, S., Teinilä, K., Salo, L., Datta, A., Simonen, P., Karjalainen, P., Kulmala, K., and Rönkkö, T.: Potential of renewable fuel to reduce diesel exhaust particle emissions, Appl. Energ., 254, 113636, https://doi.org/10.1016/j.apenergy.2019.113636, 2019.

Pohjola, M. A., Rantamäki, M., Kukkonen, J., Karppinen, A., and Berge, E.: Meteorological evaluation of a severe air pollution episode in Helsinki on 27-29 December 1995, Boreal Environ. Res., 9, 75-87, 2004.

Preble, C. V., Dallmann, T. R., Kreisberg, N. M., Hering, S. V., Harley, R. A., and Kirchstetter, T. W.: Effects of particle filters and selective catalytic reduction on heavy-duty diesel drayage truck emissions at the Port of Oakland, Environ. Sci. Technol., 49, 8864-8871, https://doi.org/10.1021/acs.est.5b01117, 2015.

Rautalahti, E. and Kupiainen, K.: Emissions of black carbon and methane in Finland, Ministry of the Environment, Helsinki, Finland, 22 pp., 2016.

Reche, C., Querol, X., Alastuey, A., Viana, M., Pey, J., Moreno, T., Rodríguez, S., González, Y., Fernández-Camacho, R., de la Rosa, J., Dall'Osto, M., Prévôt, A. S. H., Hueglin, C., Harrison, R. M., and Quincey, P.: New considerations for PM, Black Carbon and particle number concentration for air quality monitoring across different European cities, Atmos. Chem. Phys., 11, 6207-6227, https://doi.org/10.5194/acp-11-6207-2011, 2011.

Rönkkö, T. and Timonen, H.: Overview of sources and characteristics of nanoparticles in urban traffic-influenced areas, J. Alzheimer's Dis., 72, 15-28, https://doi.org/10.3233/JAD190170, 2019.

Sandradewi, J., Prévôt, A. S., Szidat, S., Perron, N., Alfarra, M. R., Lanz, V. A., Weingartner, E., and Baltensperger, U.: Using aerosol light absorption measurements for the quantitative determination of wood burning and traffic emission contributions to particulate matter, Environ. Sci. Technol., 42, 3316-3323, https://doi.org/10.1021/es702253m, 2008.

Savolahti, M., Karvosenoja, N., Tissari, J., Kupiainen, K., Sippula, O., and Jokiniemi, J.: Black carbon and fine particle emissions in Finnish residential wood combustion: Emission projections, reduction measures and the impact of combustion practices, Atmos. Environ., 140, 495-505, https://doi.org/10.1016/j.atmosenv.2016.06.023, 2016.

Singh, V., Ravindra, K., Sahu, L., and Sokhi, R.: Trends of atmospheric black carbon concentration over the United Kingdom, Atmos. Environ., 178, 148-157, https://doi.org/10.1016/j.atmosenv.2018.01.030, 2018.

Stocker, T. F., Qin, D., Plattner, G.-K., Tignor, M., Allen, S. K., Boschung, J., Nauels, A., Xia, Y., Bex, V., and Midgley, P. M.: Climate change 2013: The physical science basis, Cambridge University Press, Cambridge, UK, 2013. 
Sun, J., Birmili, W., Hermann, M., Tuch, T., Weinhold, K., Spindler, G., Schladitz, A., Bastian, S., Löschau, G., Cyrys, J., Gu, J., Flentje, H., Briel, B., Asbach, C., Kaminski, H., Ries, L., Sohmer, R., Gerwig, H., Wirtz, K., Meinhardt, F., Schwerin, A., Bath, O., Ma, N., and Wiedensohler, A.: Variability of black carbon mass concentrations, sub-micrometer particle number concentrations and size distributions: results of the German Ultrafine Aerosol Network ranging from city street to High Alpine locations, Atmos. Environ., 202, 256-268, https://doi.org/10.1016/j.atmosenv.2018.12.029, 2019.

Sun, J., Birmili, W., Hermann, M., Tuch, T., Weinhold, K., Merkel, M., Rasch, F., Müller, T., Schladitz, A., Bastian, S., Löschau, G., Cyrys, J., Gu, J., Flentje, H., Briel, B., Asbach, C., Kaminski, H., Ries, L., Sohmer, R., Gerwig, H., Wirtz, K., Meinhardt, F., Schwerin, A., Bath, O., Ma, N., and Wiedensohler, A.: Decreasing trends of particle number and black carbon mass concentrations at 16 observational sites in Germany from 2009 to 2018 , Atmos. Chem. Phys., 20, 7049-7068, https://doi.org/10.5194/acp20-7049-2020, 2020.

Teinilä, K., Aurela, M., Niemi, J. V., Kousa, A., Petäjä, T., Järvi, L., Hillamo, R., Kangas, L., Saarikoski, S., and Timonen, H.: Concentration variation of gaseous and particulate pollutants in the Helsinki city centre - observations from a two-year campaign from 2013-2015, Boreal Environ. Res., 24, 115-136, 2019.

Timonen, H., Karjalainen, P., Saukko, E., Saarikoski, S., AakkoSaksa, P., Simonen, P., Murtonen, T., Dal Maso, M., Kuuluvainen, H., Bloss, M., Ahlberg, E., Svenningsson, B., Pagels, J., Brune, W. H., Keskinen, J., Worsnop, D. R., Hillamo, R., and Rönkkö, T.: Influence of fuel ethanol content on primary emissions and secondary aerosol formation potential for a modern flex-fuel gasoline vehicle, Atmos. Chem. Phys., 17, 5311-5329, https://doi.org/10.5194/acp-17-5311-2017, 2017.

Timonen, H., Karjalainen, P., Aalto, P., Saarikoski, S., Mylläri, F., Karvosenoja, N., Jalava, P., Asmi, E., Aakko-Saksa, P. I., Saukkonen, N., Laine, T., Saarnio, K., Niemelä, N., Enroth, J., Väkevä, M., Oyola, P., Pagels, J., Ntziachristos, L., Cordero, R., Kuittinen, N., Niemi, J., and Rönkkö, T.: Adaptation of black carbon footprint concept would accelerate mitigation of global warming, Environ. Sci. Technol., 53, 1215312155, https://doi.org/10.1021/acs.est.9b05586, 2019.
Vallius, M. J., Ruuskanen, J., Mirme, A., and Pekkanen, J.: Concentrations and estimated soot content of $\mathrm{PM}_{1}, \mathrm{PM}_{2.5}$, and $\mathrm{PM}_{10}$ in a subarctic urban atmosphere, Environ. Sci. Technol., 34, 19191925, https://doi.org/10.1021/es990603e, 2000.

Virkkula, A., Mäkelä, T., Hillamo, R., Yli-Tuomi, T., Hirsikko, A., Hämeri, K., and Koponen, I. K.: A simple procedure for correcting loading effects of Aethalometer data, J. Air Waste Ma., 57, 1214-1222, https://doi.org/10.3155/1047-3289.57.10.1214, 2007.

Weichenthal, S., Farrell, W., Goldberg, M., Joseph, L., and Hatzopoulou, M.: Characterizing the impact of traffic and the built environment on near-road ultrafine particle and black carbon concentrations, Environ. Res., 132, 305-310, https://doi.org/10.1016/j.envres.2014.04.007, 2014.

Yuan, J., Modini, R. L., Zanatta, M., Herber, A. B., Müller, T., Wehner, B., Poulain, L., Tuch, T., Baltensperger, U., and GyselBeer, M.: Variability in the mass absorption cross-section of black carbon $(\mathrm{BC})$ aerosols is driven by $\mathrm{BC}$ internal mixing state at a central European background site (Melpitz, Germany) in winter, Atmos. Chem. Phys. Discuss. [preprint], https://doi.org/10.5194/acp-2020-41, in review, 2020.

Zhao, B., Jiang, J. H., Gu, Y., Diner, D., Worden, J., Liou, K.N., Su, H., Xing, J., Garay, M., and Huang, L.: Decadalscale trends in regional aerosol particle properties and their linkage to emission changes, Environ. Res. Lett., 12, 054021 , https://doi.org/10.1088/1748-9326/aa6cb2, 2017.

Zhu, Y., Hinds, W. C., Kim, S., Shen, S., and Sioutas, C.: Study of ultrafine particles near a major highway with heavy-duty diesel traffic, Atmos. Environ., 36, 4323-4335, https://doi.org/10.1016/S1352-2310(02)00354-0, 2002.

Zotter, P., Herich, H., Gysel, M., El-Haddad, I., Zhang, Y., Močnik, G., Hüglin, C., Baltensperger, U., Szidat, S., and Prévôt, A. S. H.: Evaluation of the absorption Ångström exponents for traffic and wood burning in the Aethalometer-based source apportionment using radiocarbon measurements of ambient aerosol, Atmos. Chem. Phys., 17, 4229-4249, https://doi.org/10.5194/acp17-4229-2017, 2017. 